\title{
REVIEW
}

\section{Neuroendocrine neoplasms of lung, pancreas and gut: a morphology-based comparison}

\author{
Atsuko Kasajima1,2 and Günter Klöppel1 \\ 1Department of Pathology, Technical University Munich, Munich, Germany \\ 2Member of the German Cancer Consortium (DKTK), Germany
}

Correspondence should be addressed to A Kasajima: atsuko.kasajima@tum.de

\begin{abstract}
The bronchopulmonary (BP) and gastroenteropancreatic (GEP) organ systems harbor the majority of the neuroendocrine neoplasms (NENs) of the body, comprising 20 and $70 \%$ of all NENs, respectively. Common to both NEN groups is a classification distinguishing between well- and poorly differentiated NENs associated with distinct genetic profiles. Differences between the two groups concern the reciprocal prevalence of well and poorly differentiated neoplasms, the application of a Ki67-based grading, the variety of histological patterns, the diversity of hormone expression and associated syndromes, the variable involvement in hereditary tumor syndromes, and the peculiarities of genetic changes. This review focuses on a detailed comparison of BP-NENs with GEP-NENs with the aim of highlighting and discussing the most obvious differences. Despite obvious differences, the principle therapeutical options are still the same for both NEN groups, but with further progress in genetics, more targeted therapy strategies can be expected in future.
\end{abstract}

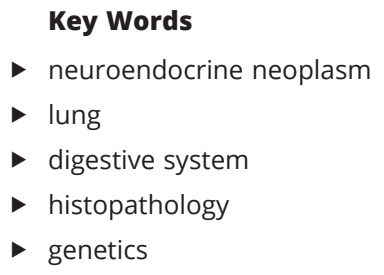

Endocrine-Related Cancer (2020) 27, R417-R432

\section{Introduction}

Neuroendocrine neoplasms (NENs) arise from various anatomical sites in the body but share basic features. NENs consist of two main families, well-differentiated NENs, also called neuroendocrine tumors (NETs) or carcinoids, and poorly differentiated NENs called neuroendocrine carcinomas (NECs) (Capella et al. 1995, Klöppel et al. $2017 a$, Rindi et al. 2018b). In fact, the similarities between the site-specific NEN entities are so large that a concept has been designed to include all NENs into a general classification (Rindi et al. 2018b).

The most important site-specific NENs are the NENs from the bronchopulmonary (BP-) and the gastroenteropancreatic (GEP) organs, as they account for over 90\% of all NENs of the body (Dasari et al. 2018). In these sites, NECs of the BP-system are approximately 20 times more frequent than NECs of the GEP-system
(8.36 vs 0.4 per 100,000 ) (Dasari et al. 2018). BP-NECs are also much more frequent than their welldifferentiated counterparts, the BP-NETs, with a ratio of approx. 7 to 1 (Gustafsson et al. 2008). The opposite is the case in the GEP-system. Here are NETs much more prevalent than NECs (ratio 5-10:1), with one notable exception, the esophagus, where almost no NETs occur (Klimstra et al. 2019). A reason for this conspicuous difference in prevalence between NETs and NECs in the BP- and GEP-systems is probably the impact of environmental cancerogenic factors. Smoking is well known as the major etiological factor in BP-NECs, making these neoplasms to the most frequent NECs in the body (Dasari et al. 2018). In the GEP-system, where smoking does not play a dominant role, NECs, like the conventional carcinomas in these localizations,
C) 2020 Society for Endocrinology Published by Bioscientifica Ltd. Printed in Great Britain 
are more associated with other environmental factors such as diet.

Other differences between the two NEN entities regard terminology, classification related grading, variability of histological patterns, variegated hormone and transcription factor expression, site-specific occurrence of functioning syndromes, occurrence of precursor lesions, involvement in hereditary diseases and complexity of the genetic landscape.

\section{Terminology, classification and grading}

Carcinoid is the term traditionally applied to the NETs of the stomach, intestinum and lung, since it was coined by Oberndorfer in 1907 in his seminal work on the NETs of the ileum, and defined by Hamperl in 1937 for the NETs of the lung (Hamperl 1937). Islet cell tumor is the term that denotes the NETs of the pancreas because of the resemblance of their cells with those of the islets. In 1995, it was suggested to call the islet cell tumor and the carcinoid of the stomach, intestinum and lung 'neuroendocrine tumor' in order to make the terminology of all these neoplasms comparable (Capella et al. 1995). In 2000 , the WHO classification of digestive system tumors took over the term neuroendocrine tumor (Solcia et al. 2000), while the 2004 WHO classification of lung tumors retained the term 'carcinoid' (Travis et al. 2004). This has resulted in the current situation that we are dealing with 'carcinoid' in the lung and 'NET' in the digestive system (Brambilla et al. 2015, Klimstra et al. 2019) (Table 1). However, since the NENs of BP- and GEP-systems are similar in terms of morphology, molecular characteristics and clinical behavior, the term BP-carcinoid could be replaced by the term BP-NET (Rindi et al. 2018b, Kasajima et al. 2019, Oka et al. 2020). The term neuroendocrine carcinoma can be retained for the poorly differentiated BP-NENs, with the small cell subtype equaling 'small cell lung carcinoma (SCLC)' and the large cell subtype equaling 'large cell neuroendocrine carcinoma (LCNEC)'. In the following, we will use this adapted terminology.

In 1972, Arrigoni described and defined typical and atypical carcinoid of the lung and correlated these two subtypes to prognosis (Arrigoni et al. 1972). The features that were found to separate two carcinoid subtypes included mitotic count and intratumoral necrosis. In 1998, Travis et al. defined typical carcinoids (TCs) by a mitotic count less than 2 mitoses per $2 \mathrm{~mm}^{2}$ and absence of necrosis, while atypical carcinoids (ACs) were characterized by $2-10$ mitoses per $2 \mathrm{~mm}^{2}$ and/or foci of necrosis (Travis et al. 1998). The two carcinoid subtypes differed in prognosis from each other, and also from SCLC and LCNEC (Travis et al. 1998). The carcinoid definition was included into the $2004 \mathrm{WHO}$ classification of the BP-system (Travis et al. 2004). In GEP-NETs, such a correlation between morphology and prognosis was only shown in the years following the publication of the $2000 \mathrm{WHO}$ classification of endocrine tumors, which included GEP-NETs (Solcia et al. 2000). In GEP-NETs, the prognostic stratification was based on the proliferative activity of the neoplasms, using mitotic count and/or the nuclear labeling of the tumor cells with the proliferation marker Ki67 (Klöppel \& La Rosa 2018). In 2010, the WHO classification graded GEP-NETs with a mitotic count of $<2 / 2 \mathrm{~mm}^{2}$ and Ki67 of $<2 \%$ as NET G1, and GEP-NETs with a mitotic count of $2-20 / 2 \mathrm{~mm}^{2}$ and Ki67 of 2-20\% as NET G2 (Bosman et al. 2010). NECs were defined in this grading system as neoplasms with mitotic count above $20 / 2 \mathrm{~mm}^{2}$ and/or Ki67 index above 20\% (Bosman et al. 2010). When these three groups were correlated to survival, a clear-cut prognostic significance became apparent (Pape et al. 2008, Jann et al. 2011).

Table 1 WHO classifications of neuroendocrine neoplasms of bronchopulmonary (BP) and gastroenteropancreatic (GEP) neuroendocrine neoplasms (BP-NEN WHO 2015 and GEP-NEN WHO 2019).

\begin{tabular}{|c|c|c|c|c|c|c|c|}
\hline \multirow[b]{2}{*}{ Differentiation } & \multicolumn{4}{|c|}{ BP-NEN } & \multicolumn{3}{|c|}{ GEP-NEN } \\
\hline & Terminology & Mitoses per $2 \mathrm{~mm}^{2}$ & Necrosis & Ki67 indexa & Terminology & Mitoses per $2 \mathrm{~mm}^{2}$ & Ki67 index \\
\hline \multirow{3}{*}{ Well-differentiated } & $\mathrm{TC}$ & $0-1$ & No & up to $5 \%$ & NET G1 & $<2$ & $<3 \%$ \\
\hline & $A C$ & $2-10$ & Focal, if any & up to $20 \%$ & NET G2 & $2-20$ & $3-20 \%$ \\
\hline & & & & & NET G3 & $>20$ & $>20 \%$ \\
\hline \multirow[t]{2}{*}{ Poorly differentiated } & LCNEC & $>10$ & Yes & $40-80 \%$ & Large cell type (LCNEC) & $>20$ & $>20 \%$ \\
\hline & SCLC & $>10$ & Yes & $50-100 \%$ & Small cell type (SCNEC) & $>20$ & $>20 \%$ \\
\hline $\begin{array}{l}\text { Mixed NE and } \\
\text { non-NE neoplasms }\end{array}$ & \multicolumn{4}{|c|}{ Combined SCLC / LCNECb } & MiNENc & & \\
\hline
\end{tabular}

aNot included in criteria; bAmount of the non-NEN components is not defined; cEach component accounts for at least 30\% of total tumor cell population. TC, typical carcinoid; AC, atypical carcinoid; LCNEC, large cell neuroendocrine carcinoma; SCLC, small cell lung carcinoma; NE, neuroendocrine; NET, neuroendocrine tumor; NEC, neuroendocrine carcinoma; MiNEN, mixed neuroendocrine and non-neuroendocrine neoplasm.

(c) 2020 Society for Endocrinology Published by Bioscientifica Ltd. Printed in Great Britain 
In 2014, Rindi et al. proposed a prognosis-relevant threetiered grading of BP-NENs on the basis of three variables: mitotic count, Ki67 index and necrosis (Rindi et al. 2014). This grading, however, was not included into the WHO classification of the BP-system tumors published in 2015 (Brambilla et al. 2015).

In the years following the release of the 2010 WHO classification of digestive system tumors, it was increasingly recognized, especially in pancreatic NETs (PanNETs), that some NETs presented with a Ki67 index greater than $20 \%$ that qualifies such a tumor for a NEC, when the 2010 WHO classification was applied. However, careful analysis of such tumors revealed that they had retained their typical well-differentiated histology and functional capacity and did not transform into NECs. For the PanNETs, it was thus concluded that they can overlap in their proliferative activity with PanNECs, but still belong to the NET category (Klöppel et al. 2017a). The WHO classification from 2017 for endocrine organ tumors, including PanNENs, added, therefore, a PanNET G3 category, defined by a Ki67 index exceeding 20\%, to the existing PanNEN categories (Klöppel et al. 2017a). The WHO 2019 classification for GEP-NENs finally adapted the NET G3 category for all NENs of the digestive system (Klimstra et al. 2019).

In the BP-system, a number of studies focused on a prognostic segregation using the proliferation marker Ki67. Although most of the studies found a correlation between defined Ki67 index groups and prognosis, they are difficult to compare because of the use of different cut-off values (Volante et al. 2015, Naheed et al. 2019), and the 2015 WHO classification did not use the data from these studies to develop a detailed grading system comparable to that of the digestive system NENs. Recently, others and we identified a small group of BP-NENs with well-differentiated morphology, a mitotic count of more than 10 per $2 \mathrm{~mm}^{2}$ and/or a Ki67 index greater than 20\% (Quinn et al. 2017, Kasajima et al. 2019, Oka et al. 2020, Rekhtman et al. 2019, Cros et al. 2020). Interestingly a similar group was recently described in thymic NENs (Dinter et al. 2019). In our study on 393 BP-NENs from Japan and Germany, we applied the 2019 WHO classification of digestive system tumors and found that BP-NETs G1 largely corresponded to TCs, while ACs corresponded to BP-NETs G2, and a few ACs and LCNECs corresponded to BP-NET G3 (Oka et al. 2020). The prevalence of primary BP-NETs G3 in our total cohort of BP-NENs was 4\% (Kasajima et al. 2019, Oka et al. 2020). This NET G3 prevalence matches that of thymic NENs (5\%) (Dinter et al. 2019), but is slightly higher than that reported for the pancreas (2\%) (Rindi et al. 2018a). The percentage of BP-NETs G3, however, can increase to up to $27 \%$ in the course of the disease, as has recently been reported for Stage IV metastatic BP-NETs (Rekhtman et al. 2019). The outcome of the BP-NET G3 patients in our study was significantly worse than that of BP-NET G1/G2 patients but statistically not different from that of BP-NEC patients. After a course of 5 years, BP-NET G3 patients showed a rapid worsening in survival (Oka et al. 2019), similar to the clinical outcome reported in a large series of PanNETs (Rindi et al. 2018a).

Taken together, all the studies clearly show that BP-NENs, like GEP-NENs, can be effectively classified into prognosis relevant groups, using the Ki67 based grading system of GEP-NENs. It is particularly possible to sort out the special group of NETs G3, which morphologically, and as will be shown later, genetically relate to the well-differentiated NEN category, although clinically they behave like poorly differentiated NENs. This intriguing group of NENs that so far only includes a relatively small number of cases has to be further investigated in larger series, considering morphology, genetics and biology. In addition, the BP-NET G3 histology needs a more refined definition.

The GEP-NEN 2019 WHO classification also includes the category of mixed neuroendocrine nonneuroendocrine neoplasms (MiNENs), formerly referred to as mixed adenoneuroendocrine carcinomas (MANECs) (Table 1). MiNEN is a conceptional approach to a group of tumors that is not really an entity but consists of neoplasms, which, although mostly monoclonal, show a variable mixture of non-neuroendocrine cell elements (i.e. adenocarcinoma or squamous cell carcinoma) with usually poorly differentiated neuroendocrine cells (Klöppel et al. 2017a, Klimstra et al. 2019). The WHO classification of digestive system tumors defines MiNEN as neoplasm, in which each component accounts for more than $30 \%$ of the tumor cell population (Klimstra et al. 2019). In the BP-system, mixed neoplasms corresponding to MiNEN also exist, but are called combined SCLC or LCNEC. However, the definition of these combined neoplasms is not as clear as that of MiNEN, because of the largely lacking quantification of the different components. Only in the SCLC that is combined with LCNEC, it is stated that the LCNEC component should exceed $10 \%$ of the tumor cell population (Brambilla et al. 2015). No quantification is recommended, if SCLC or LCNEC is combined with an adenocarcinoma, a squamous cell carcinoma, a giant cell carcinoma or a spindle cell carcinoma component (Brambilla et al. 2015). MiNENs and combined SCLC/LCNECs have received 
increased attention, due to their more frequent detection by the common use of immunohistochemical markers (La Rosa et al. 2016, 2018), and are currently under discussion concerning their biological and prognostic features as well as special treatment (Qin \& Lu 2018, Frizziero et al. 2019, Zhang et al. 2020).

\section{Histology and hormone production}

In general, all NETs and NECs of the body have similar histology, but among the NETs there are some organspecific growth patterns. Common to BP-NETs and GEP-NETs are solid and trabecular patterns, but in the digestive tract system, in contrast to the lung, these two basic patterns may show very specific variations, particularly in the pancreas, the periampullary duodenum, the ileum, the appendix and the rectum (Table 2). In the pancreas, a trabecular pattern connected with amyloid deposition is associated with insulin expression. Reticulated trabecular pattern and cystic changes are often observed in PanNETs with glucagon expression (Konukiewitz et al. 2011). Paraganglioma-like solid patterns are linked to the expression of somatostatin (Garbrecht et al. 2008, Konukiewitz et al. 2020). Solid architecture and sclerotic stroma are indicative of serotonin expression (McCall et al. 2012). In the duodenum, the periampullary NETs with glandular pattern and psammoma bodies express almost exclusively somatostatin (Garbrecht et al. 2008). In the ileum and the appendix, NETs with a solid and cribriform pattern and peripheral palisading usually label for serotonin. In the rectum, a solid glandular pattern associates with glucagon and pancreatic polypeptide (PP) expression. Moreover, the rectal NETs express the transcription factor islet 1 (ISL1) (Agaimy et al. 2013), relating these NETs closely to PanNETs. All these observations demonstrate that certain neuroendocrine cell types are associated with typical architectural features of the respective tumors. The mechanisms behind these functional-structural relationships are so far not known, but it is conceivable that certain cell type specific genetic changes determine the structure of the tumors.

In contrast to the GEP-NETs with a spectrum of distinctive structural and functional features, the BP-NETs are rather simple. None of the commonly expressed hormones, that is, gastrin-related peptide (GRP), serotonin, calcitonin and/or adrenocorticotropin (ACTH) (Bonato et al. 1992), is combined with any particular histological pattern. Even the most conspicuous pattern, the solid-spindle cell pattern, shows neither special hormone expression, nor a clear site-specific relationship (Tsuta et al. 2011). It seems, therefore, that the hormonal status of BP-NET cells does not have a major impact on the architectural composition of the tumors.

\section{Immunohistochemical markers other than hormones}

Apart from the hormones that are expressed in BPand GEP-NENs, there are other immunohistochemical

Table 2 Association between tumor site, histological pattern, and hormone expression in bronchopulmonary and gastroenteropancreatic neuroendocrine neoplasms (BP-NENs and GEP-NENs).

\begin{tabular}{|c|c|c|c|c|}
\hline & Type & Site & Morphology & Hormone \\
\hline \multirow[t]{3}{*}{ BP-NENS } & $\mathrm{TC}$ & Central & Trabecular > solid & Various hormonesa \\
\hline & $A C$ & Peripheral & Solid and spindle cell> trabecular & Various hormonesa \\
\hline & NEC & Peripheral & Large cell > small cell & - \\
\hline \multirow[t]{13}{*}{ GEP-NENS } & NET & Pancreas & Solid, trabecular & Various hormonesb \\
\hline & NET & Pancreas & Trabecular, amyloid deposition & Insulin \\
\hline & NET & Pancreas & Reticulated-trabecular, cystic & Glucagon \\
\hline & NET & Pancreas & Solid, paraganglioma-like & Somatostatin \\
\hline & NET & Pancreas & Solid, sclerosing & Serotonin \\
\hline & NET & Ileum & Solid, cribriform, palisading & Serotonin \\
\hline & NET & Appendix & Solid, cribriform, palisading & Serotonin \\
\hline & NET & Appendix & Tubular & Glucagon \\
\hline & NET & Stomach & Solid, glandular & ECL-histamine \\
\hline & NET & Duodenum & Solid, glandular & Gastrin \\
\hline & NET & Duodenum & Glandular, psammoma body & Somatostatin \\
\hline & NET & Rectum & Solid, glandular & Glucagon, PP \\
\hline & NEC & No preferential site & Large cell >> small cell & Unusually, no hormone \\
\hline
\end{tabular}

aACTH, GRP, calcitonin, serotonin are slghtly more common in the periphery than in the hilar lesion; bInsulin, PP, somatostatin, gastrin, VIP, ACTH. AC, atypical carcinoid; ACTH, adrenocorticotropin; ECL, enterochromaffin-like cell; GRP, gastrine-related peptide; NEC, neuroendocrine carcinoma; NET, neuroendocrine tumor; PP, pancreatic polypeptide; TC, typical carcinoid.

(c) 2020 Society for Endocrinology Published by Bioscientifica Ltd. Printed in Great Britain 
markers that play a role in diagnosing, characterizing and identifying these neoplasms (Table 3). Of significance for the differential diagnosis are CK7, TTF-1, ISL1 and CDX2. Somatostatin receptor 2 (SST2), on the other hand, is a molecular marker of significant diagnostic and therapeutic importance.

\section{Cytokeratin and neuroendocrine markers}

Expression of CK18 is observed in BP- and GEP-NENs and proves the epithelial nature of these tumors. Interestingly, CK7, a cytokeratin usually seen in adenocarcinomas, is expressed in $60 \%$ of BP-NETs, whereas it is negative or very occasionally positive in GEP-NETs (Chan et al. 2012). NECs, which all express CK18, though to a variable extent, often exhibit a conspicuous dot-like staining pattern.

For the proof of neuroendocrine differentiation of the neoplasms labeling with synaptophysin (SYN) and chromogranin A ( $\mathrm{CgA})$ is required in GEP-NENs (Klimstra et al. 2019). The expression of CD56, a cell membrane-bound glycoprotein, can be a helpful adjunct in case of weak SYN and CgA stainings. However, positivity of CD56 that is not accompanied by SYN and CgA expression, does not prove the neuroendocrine nature of the tumor (Klöppel et al. 2017a), since it is expressed not only in NENs but also in various other neoplasms, including basaloid squamous cell carcinoma, Ewing sarcoma, synovial sarcoma, chondrosarcoma or poorly differentiated neoplasms. Therefore, the statement in the WHO 2015 classification that CD56 positivity alone is enough to prove the neuroendocrine nature of BP-NENs (Brambilla et al. 2015) has, therefore, to be reconsidered in future classification of these tumors. Insulin-associated protein 1 (INSM1) has been proposed as a new neuroendocrine marker with high sensitivity (over $90 \%$ in both NETs and NECs), but needs to be further studied (Fujino et al. 2015, Rooper et al. 2017).

\section{Transcription factors}

TTF-1 is expressed in type II alveolar cells, Clara cells, and neuroendocrine cells in the peripheral airways of the lung. In BP-NETs, TTF-1 expression is more often seen in peripheral tumors (73\%) than in central tumors (23\%) (La Rosa et al. 2010). In GEP-NETs, and also in thymic NETs, TTF-1 is mostly negative (Chan et al. 2012). Thyroid medullary carcinoma and larynx NETs strongly express TTF-1, but can be differentiated from BP-NETs by the co-expression of CEA and calcitonin. In BP-NECs, TTF-1 is expressed in $84 \%$ of SCLCs, $77 \%$ of LCNECs) (La Rosa et al. 2010). However, it is also expressed in GEP-NECs (up to 15\%) (La Rosa et al. 2010) and other

Table 3 Immunohistochemical markers of bronchopulmonary and gastroenteropancreatic neuroendocrine neoplasms (BP-NENs and GEP-NENs).

\begin{tabular}{|c|c|c|c|c|c|}
\hline & & \multicolumn{2}{|r|}{ BP-NENS } & \multicolumn{2}{|r|}{ GEP-NENs } \\
\hline & & NET (TC/AC) & NEC (LCNEC/SCLC) & NET & NEC \\
\hline \multirow[t]{2}{*}{ Neuroendocrine markers } & CgA & Diffuse & Focal & Diffuse $^{a}$ & Focal \\
\hline & SYN & Diffuse & Variable & Diffuse & Variable \\
\hline \multirow[t]{3}{*}{ Cytokeratins } & CK7 & $60 \%$ & Focal & Neg & Neg \\
\hline & CK20 & Neg & $0-5 \%$ & $10-30 \%$ & Focal \\
\hline & CK8/18 & Diffuse & Focal & Diffuse, strong & Focal \\
\hline Cell cycle markers & p53/Rb1 & Normal & Overexpression/loss & Normal & Overexpression/loss \\
\hline \multirow[t]{5}{*}{ Transcription factors } & TTF1 & $30-50 \%$ & $30-80 \%$ & Neg & Focal, weak \\
\hline & ISL1 & Neg & $80-100 \%$ & $80 \% \mathrm{~b}$ & Neg \\
\hline & PDX1 & $10 \%$ & - & $60 \% c$ & - \\
\hline & PAX8 & $8 \%$ & 40\% (weak) & $80 \% d$ & Weak \\
\hline & CDX2 & Neg & $0-25 \%$ & Diffuse & $50-80 \%$ \\
\hline \multirow[t]{5}{*}{ Peptide hormones } & Serotonin & $30-60 \%$ & - & Diffusef $^{f}$ & $5 \%$ \\
\hline & Calcitonin & $5-40 \%$ & $20 \%$ & Rare & Rare \\
\hline & ACTH & $25 \%$ & $5 \%$ & Rare & Neg \\
\hline & GRP & $40-80 \%$ & Neg & Neg & - \\
\hline & PTHrP & $<1 \%$ & Rare & Neg & Neg \\
\hline Receptor marker & SST2A & $30-100 \%$ & $50-70 \%$ & $70-100 \%$ & $<10 \%$ \\
\hline
\end{tabular}

aApart from rectal NET; bPancreas, duodenum and rectum; cPancreas, stomach and appendix; dPancreas and rectum; eGI tract; fmidgut. AC, atypical carcinoid; ACTH, adrenocorticotropin; BP, bronchopulmonary; CDX2, homeobox gene; CgA, chromogranin A; CK, cytokeratin; GI, gastrointestinal; GRP, gastrin related peptide; ISL1, islet gene enhancer protein 1; ; LCNEC, large cell neuroendocrine carcinoma; NEC, neuroendocrine carcinoma; NET, neuroendocrine tumor; PAX8, paired box gene 8; PDX1, pancreatic and duodenal homeobox 1; PTHrP, paratholmon-related protein; Rb1, retinoblastoma 1; SCLC, small cell lung carcinoma; ; SST2A, somatostatin receptor 2A; SYN, synaptophysin; TC, typical carcinoid; TTF1, thyroid transcription factor. 
extrapulmonary NECs, such as larynx, urinary bladder, prostate and uterine cervix NECs (La Rosa et al. 2010).

Nuclear orthopedia homeobox (OTP) is a recently introduced transcription factor as highly specific marker for BP-NETs and is only occasionally expressed in NECs and NENs of other organs (Papaxoinis et al. 2017, Moonen et al. 2019).

ISL1 plays a crucial role in embryogenesis and differentiation of pancreatic beta cells and is expressed in almost 90\% of PanNETs (including duodenal and ampullary NETs) but negative in BP-NETs (Agaimy et al. 2013). Therefore it is useful to distinguish BP- from GEP-NETs, particularly in case of a NET liver metastasis with unknown primary. In PanNECs, ISL1 is usually negative, while it is frequently positive in BP-NECs and medullary thyroid carcinomas (Agaimy et al. 2013).

Pancreatico-duodenal homeobox 1 gene product (PDX-1) is also an essential transcription factor in embryonic development of beta cell and intestinal neuroendocrine cells. PDX-1 is frequently expressed in insulin-producing PanNETs, also in duodenal and ileal NETs, but not in BP-NETs (Hermann et al. 2011, Yang et al. 2018).

CDX2 (Homeobox protein) regulates the development of intestinal epithelial cells. CDX2 is expressed in small and large intestine NETs and in few PanNETs, but constantly negative in BP-NETs (Chan et al. 2012). In BP-NECs and also GEP-NECs, CDX2 may be occasionally expressed (Bari et al. 2014, Lee et al. 2018).

\section{Somatostatin receptors}

SST2A labeling is strongly correlated to somatostatin receptor radio diagnosis and therapy. Interestingly, SST2A is expressed in almost all GEP-NETs, excluding insulinomas (where it is only positive in $50 \%$ of the cases), while it is only seen in about $50 \%$ of BP-NETs (Righi et al. 2010, Kaemmerer et al. 2015, Kasajima et al. 2019). In BP-NECs, SST2A labels $35-60 \%$ of the tumors (Righi et al. 2010, Kaemmerer et al. 2015, Kasajima et al. 2019, Oka et al. 2019), while in GEP-NECs, it is only positive in about $10 \%$ (Konukiewitz et al. 2017). The reason for this differential expression of SST2A in BP- and GEP-NENs is not known so far. The fact that SST2A also labels about $35-60 \%$ of BP-NECs offers an interesting treatment option for these neoplasms, although PRRT efficacy in these tumors has been questioned (Sollini et al. 2013). SST5 shows also a high affinity to somatostatin analogs and its expression is observed in $30-50 \%$ of BP-NETs (Vesterinen et al. 2019).

\section{Functioning syndromes}

Fifteen peptide hormone-producing neuroendocrine cells are found in the GEP-organs. They are involved in endocrine regulation, enzyme secretion or intestinal motility. Of the 15 peptide hormones, only 7 (insulin, glucagon, somatostatin, PP, gastrin, serotonin, histamine) show a significant production in GEP-NET cells. The normal lung contains GRP and calcitonin-producing cells (Tsutsumi 1989), and these cells are also frequently found in BP-NENs (Bonato et al. 1992). Hormones that are ectopic to the lung and/or the GEP-systems, but may occur in respective NETs are ACTH, vasoactive intestinal peptide (VIP), growth hormone-releasing hormone (GHRH), serotonin (only in the lung), antidiuretic hormone (ADH) and parathormon-related protein (PTHrP). Most important is ACTH, as it is frequently expressed in BP-NETs (25\%) (La Rosa et al. 2019), and is associated with Cushing syndrome in up to $5 \%$ of these tumors. It has no prognostic impact compared to non-ACTH producing BP-NETs (La Rosa et al. 2019). The reason for the common expression of ACTH in BP-NET cells is not known. In the GEP system, ACTH producing NETs are rare but occur most frequently in the pancreas (Maragliano et al. 2015). These ACTH producing PanNETs are often metastasizing and multihormonal. In the clinical course of the disease, the patients may present with Zollinger-Ellison syndrome or hyperinsulinemic hypoglycemia, before Cushing syndrome becomes overt (Maragliano et al. 2015).

The NENs associated with hormone production and hormonal syndromes are almost exclusively NETs. There are a number of reports in the literature, which associate SCLC with hormone production and syndromes, notably ACTH and Cushing syndrome, as well as ADH and syndrome of inappropriate ADH secretion (Seute et al. 2004). However, the presented evidence for ACTH or ADH production and small cell morphology is often scarce or completely missing.

Functioning tumors are much more common among GEP-NETs than BP-NETs (Gustafsson et al. 2008, Pape et al. 2008, Jann et al. 2011) (Table 4). In the GEP-system most functioning tumors derive from orthotopic cells, that is, serotonin cells in the ileum, gastrin cells in the duodenum, and insulin and glucagon cells in the pancreas. Most frequent is the carcinoid syndrome that is found in $28 \%$ of GEP-NETs (Pape et al. 2008, Jann et al. 2011) and is most commonly associated with NETs in the ileum and only rarely with NETs in the pancreas and the lung (La Rosa et al. 2011, McCall et al. 2012, Halperin et al. 2017). Since the functionally active metabolites of serotonin are 
mainly produced in the liver, the carcinoid syndrome typically occurs after intensive metastasis to the liver (Halperin et al. 2017). BP-NETs are positive for serotonin in 30-60\% of the cases (Bonato et al. 1992, Vesterinen et al. 2018), but rarely associate with a carcinoid syndrome (Halperin et al. 2017) (Table 4). Serotonin expressing ileal and pancreatic NETs show an intensive sclerotic stroma, which is probably the result of the promoting effects of serotonin on fibroblast growth factor (McCall et al. 2012). Because in the pancreas the serotonin positive PanNETs often locate adjacent to the main pancreatic duct, these tumors cause duct stenosis with upstream dilatation

Table 4 Functioning disease associated bronchopulmonary and gastroenteropancreatic neuroendocrine tumors (BP-NETs and GEP-NETs).

\begin{tabular}{|c|c|c|c|}
\hline & Syndrome & $\begin{array}{l}\text { Prevalence }(\%) \\
\text { and type }\end{array}$ & Hormone \\
\hline \multirow[t]{9}{*}{ BP-NETg } & $\begin{array}{l}\text { Functioning: } \\
\text { non-functioning (100\%) }\end{array}$ & $5 \%: 95 \%$ a & \\
\hline & Cushing syndrome & $1-4.3 \% \%^{a, b, c}$ & ACTH \\
\hline & Carcinoid syndrome & $1.6-8 \% \mathrm{a}, \mathrm{d}, \mathrm{e}$ & Serotonin \\
\hline & Acromegaly & Rare & $\mathrm{GHRH}$ \\
\hline & Hypercalcemia & Rare & PTHrP \\
\hline & Hyponatremia & Rare & $\mathrm{ADH}$ \\
\hline & No defined syndrome & Common & Calcitonin \\
\hline & No defined syndrome & Common & GRP \\
\hline & No defined syndrome & Rare & Othersh \\
\hline \multirow[t]{12}{*}{ GEP-NET } & $\begin{array}{l}\text { Functioning: non- } \\
\text { functioning (100\%) }\end{array}$ & $35 \%: 65 \%{ }^{f}$ & \\
\hline & Carcinoid syndrome & $28 \%$ SI-NETf,i & Serotonin \\
\hline & Other syndromes & $7 \% \mathrm{f}$ & \\
\hline & Insulinoma & PanNET & Insulin \\
\hline & ZES & $\begin{array}{c}\text { Duo- and } \\
\text { PanNET }\end{array}$ & Gastrin \\
\hline & Glucagonoma & PanNET & Glucagon \\
\hline & $\begin{array}{l}\text { Verner-Morrison } \\
\text { syndrome }\end{array}$ & PanNET & VIP \\
\hline & Cushing syndrome & $\begin{array}{l}\text { Pan and } \\
\text { GI-NET }\end{array}$ & ACTH \\
\hline & Acromegaly & PanNET & GHRH \\
\hline & Hypercalcemia & PanNET & PTHrP \\
\hline & No defined syndrome & PanNET & Calcitonin \\
\hline & No defined syndrome & $\begin{array}{l}\text { Pan- and } \\
\text { GI-NET }\end{array}$ & Othersj \\
\hline
\end{tabular}

aGustafsson et al. 2008; bGranberg et al. 2000; cLa Rosa et al. 2019; dDaddi et al. 2014; eHalperin et al. 2017; fPape et al. 2008 \& Jann et al. 2011; gln the literature, SCLC is often mentioned as Cushing syndrome causing primary tumor, but morphological and immunohistochemical evidence is rare/not existent; hPancreatic polypeptide (PP), human choriogonadotrophic hormone beta, enkephalin; IIncludes 3\% PanNETs; SSomatostatin, PP and cholecystokinin in PanNET, histamin in gastric NET.

ACTH, adrenocorticotropin; ADH, antidiuretic hormone; Duo-NET, duodenal NET; GHRH, growth hormone-releasing hormone; GI-NET, gastrointestinal NET; GRP, gastrin-related peptide; NET, neuroendocrine tumor; PanNET, pancreatic NET; PTHrP, parathormon-related protein; SI-NET, small intestinal NET; VIP, vasoactive intestinal peptide.
(McCall et al. 2012). Appendiceal NETs also produce serotonin, but there is no convincing report associating these NETs with a carcinoid syndrome, most likely because they almost never metastasize to the liver.

GRP expressing NETs are exclusively found in the lung and are not associated with any defined hormonal syndrome. Calcitonin is not only expressed in the lung, where it is found in 5-40\% of BP-NETs (Tsutsumi 1989, Nozieres et al. 2016, Vesterinen et al. 2018), but also in about $10 \%$ of PanNETs, where it often occurs together with other hormones (Uccella et al. 2017). Calcitonin is secreted into the circulation but a well-defined hormonal syndrome is missing, although some of the patients may present with diarrhea, and/or hypercalcemia or have carcinoid syndrome or Cushing syndrome (Nozieres et al. 2016).

$\mathrm{PTHrP}$ expression is detected in various types of lung carcinomas, especially in lung squamous cell carcinoma. Hypercalcemia due to PTHrP production in BP-NETs is very rare, reported in less than $1 \%$ of the patients, and exceedingly seldom in GEP-NETs (Daskalakis et al. 2019). Also very rare is acromegaly caused by ectopic GHRH but may occur in both BP- and GEP-NETs (Daddi et al. 2014) (Table 4).

\section{Precursor lesions and hereditary tumor syndromes}

Precursor lesions to NENs have been observed in diffuse idiopathic neuroendocrine cell hyperplasia (DIPNECH) of the lung and in forerunners to multiple endocrine neoplasia type 1 (MEN1) associated NETs of the lungs, pancreas, duodenum and stomach, as well as in the stomach with chronic atrophic gastritis. Precursor lesions to VHL associated NETs are restricted to the pancreas and have never been observed in the lung.

DIPNECH is a complex disease. It is defined by multifocal neuroendocrine cell hyperplasia in the bronchiolar epithelium, by the occurrence of tumorlets (small endocrine cell foci $<0.5 \mathrm{~cm}$ ) and/or BP-NETs around a terminal bronchiole, and by chronic obstructive changes of the bronchioles (Brambilla et al. 2015). The patients present obstructive bronchiolitis with asthmalike symptoms and chronic functional lung impairment (Mengoli et al. 2018). DIPNECH BP-NETs were thought to be indolent but recently a metastatic rate of $13 \%$ has been reported in 46 patients (Hayes et al. 2018). Cause and pathogenesis of the disease are not known. DIPNECH frequently expresses peptide hormones, including GRP, 
calcitonin and occasionally ACTH (Mengoli et al. 2018). It is not associated with any hormone-related symptom. So far, no familial background has been observed in DIPNECH patients, but the disease may be, though very rarely, associated with MEN1 (Bartsch et al. 2016). DIPNECH has to be distinguished from neuroendocrine cell hyperplasia that may occur adjacent to various lung tumors in up to $30 \%$ (Rizvi et al. 2009).

In the GEP organs, NET precursor lesions are seen in the stomach, the duodenum and pancreas. They are mostly associated with MEN1, with one notable exception. This is the occurrence of multiple enterochromaffin cell like (ECL)-cell NETs in the stomach in the presence of chronic atrophic corpus gastritis with intestinal metaplasia. The ECL-cell hyperplasia is induced and stimulated by the hypergastrinemia that follows the disappearance of parietal cells in the development of autoimmune chronic atrophic gastritis. The tumors are usually indolent and can be controlled by endoscopic removal.

The precursor lesions seen in MEN1 patients with BP-NETs were described as linear and micronodular neuroendocrine cell hyperplasia in subsegmental bronchi (Bartsch et al. 2016). BP-NETs manifest in about 3-13\% of the MEN1 patients, a frequency that is much lower than that observed in GEP-organs affected by MEN1 tumors (50-70\%) (Bartsch et al. 2016, Klöppel et al. 2017a). So far, all MEN1-associated BP-NETs were found to be hormonally inactive (Bartsch et al. 2016). Hormonal syndromes, in contrast, occur frequently in MEN1-associated GEP-NETs, duodenal gastrinomas and pancreatic insulinomas being observed in up to 50 and $35 \%$ of the patients, respectively (Klöppel et al. 2017a). These tumors are preceded by microadenomas that in the pancreas, most often express glucagon (Perren et al. 2007) and/or PP, and in the duodenum gastrin or somatostatin (Anlauf et al. 2006). BP- and PanNETs arising in MEN1 patients are usually low grade (mostly G1) and the patients show a 10-year survival of over 70\% (de Laat et al. 2014). Aggressive NETs, as they occur in the thymus with a reported 10-year survival of $25 \%$, are not seen in the BP- and GEP-system (de Laat et al. 2014).

Patients with VHL may develop PanNETs, that often show clear/lipid-rich cells, and have microadenomas in about $70 \%$ of the cases (Perigny et al. 2009). Neurofibromatosis 1 (NF1) patients may show periampullary NETs with somatostatin expression and psammoma body manifestation (Garbrecht et al. 2008). No manifestation of NF1 has been so far reported in the lung.

\section{Genetic alterations}

Recent studies, using whole-genome or targeted gene sequencing, have tremendously increased our understanding of the main genetic alterations in BP- and GEP-NENs (Table 5). In GEP-NENs, the data so far available concern mainly PanNENs and, to a small extent, ileal NENs. Ileal NENs differ distinctly in their genetic profile from that of BP-NENs and PanNENs, and are therefore separately discussed (see subsequently), while BP-NENs and PanNENs share a number of genetic features.

Common to both BP- and PanNENs is the morphologic and genetic dichotomy characterized by frequent MEN1 mutations in NETs as opposed to frequent TP53 and RB1 mutations in NECs (George et al. 2015, Rekhtman et al. 2016, Scarpa et al. 2017, Simbolo et al. 2017). This genetic dichotomy is also shared with a number of other NENs of the body (Klöppel 2017). Also common to NETs and NECs of the lung and pancreas are the frequent alterations in chromatin remodeling genes (Scarpa et al. 2017, Simbolo et al. 2017, Asiedu et al. 2018).

Differences between BP- and PanNENs concern the frequency of MEN1 alterations (BP-NETs 11-18\% vs PanNETs 36-44\%), and the near absence of DAXX/ ATRX mutations in BP-NETs (less than 1\%) as opposed to PanNETs (25-43\%) (Jiao et al. 2011, Fernandez-Cuesta et al . 2014, Swarts et al. 2014, Scarpa et al. 2017, Simbolo et al. 2017, Chan et al. 2018, Alcala et al. 2019) (Table 5). In BP-NETs, MEN1 alterations are somewhat more common in ACs than in TCs (Swarts et al. 2014, Simbolo et al. 2017, Alcala et al. 2019).

The reason why the MEN1 gene is more frequently affected in PanNETs than in BP-NETs is not known so far. It might, however, be an indication that the neuroendocrine cells of the lung differ in their biology from pancreatic neuroendocrine cells. This might also be the reason of the different frequency of BP- and PanNETs in MEN1 patients. While PanNETs occur in about $50-70 \%$ of MEN1 patients, BP-NETs are present in less than 10\% (Goudet et al. 2011, Bartsch et al. 2016). In PanNETs, MEN1 mutations are detected in the early phase of the tumor development, since loss of menin, that indicates MEN1 mutation, is frequently observed in microadenomas of the pancreas (Hackeng et al. 2016). In the MEN1-pancreas the development of microadenomas is characterized by biallelic inactivation of the MEN1 gene. The latter observations together with the frequency of MEN1 mutations in PanNETs suggest that the MEN1 gene most likely acts as a driver gene in PanNETs, 
Table 5 Comparison of common genetic alterations in bronchopulmonary and pancreatic neuroendocrine neoplasms (BP-NENs and PanNENs).

\begin{tabular}{ll}
\hline NET & Gene \\
\cline { 1 - 1 } & MEN1 \\
& DAXX/ATRX \\
& Other chromatin-remodelling genes ${ }^{\circ}$ \\
& mTOR signaling genes \\
& TP53/Rb1 \\
& TP53 \\
& Rb1/p16 \\
& Other chromatin-remodelling genes ${ }^{\circ}$ \\
& KRAS \\
& mTOR signaling genes \\
& MEN1 \\
& DAXX/ATRX \\
\end{tabular}

\begin{tabular}{c}
\hline BP-NENs \\
\hline Prevalence $(\%)$ \\
\hline $11-18 \%^{a}, \mathrm{~b}, \mathrm{c}, \mathrm{l}$ \\
$<1 \%^{\mathrm{a}}$ \\
$46 \%^{\mathrm{a}, \mathrm{d}}$ \\
$2 \%^{\mathrm{a}}$ \\
$<10 \%^{\mathrm{a}}$ \\
$70-90 \%^{\mathrm{a}, \mathrm{m}}$ \\
$70 \%^{\mathrm{a}}$ \\
$55 \%^{\mathrm{a}}$ \\
$10 \%^{\mathrm{a}, \mathrm{n}}$ \\
$12 \%^{\mathrm{a}}$ \\
$<1 \%^{\mathrm{a}}$ \\
$<1 \%^{\mathrm{a}}$
\end{tabular}

\begin{tabular}{|c|}
\hline PanNENs \\
\hline Prevalence (\%) \\
\hline 37-44\%e,f,g \\
\hline $25-43 \%$ e,f,g,h,l \\
\hline $50 \%$ e \\
\hline $12-15 \%$ e,f,g,l \\
\hline$<3 \% \mathrm{e}^{\mathrm{e}, \mathrm{f} \mathrm{g}}$ \\
\hline $70-90 \% \mathrm{i}, \mathrm{j}$ \\
\hline $50-60 \%$ i, j \\
\hline NA \\
\hline $30-40 \% \mathrm{i}, \mathrm{j}$ \\
\hline NA \\
\hline $0 \% \mathrm{j}$ \\
\hline $0 \%{ }^{k}$ \\
\hline
\end{tabular}

aSimbolo et al. 2017; bSwarts et al. 2014; cAlcala et al. 2019; dFernandez-Cuesta et al. 2014; eScarpa et al. 2017; fChan et al. 2018; gjiao et al. 2011; hSinghi et al. 2017; iYachida et al. 2012; jKonukiewitz et al. 2018; kKonukiewitz et al. 2017; 'Associated with high grade tumor; mA higher prevalence of TP53/Rb1 biallelic mutation in small cell lung carcinoma than in large cell neuroendocrine carcinoma (LCNEC); nDetected in LCNEC; olncludes ARID family in BP and PanNET. EIF1AX and KMT2 family in BP-NEN, STED2 and MLL3 in PanNET.

NA, no data available; NEC, neuroendocrine carcinoma; NET, neuroendocrine tumor.

while it seems to play no significant role in the development of most BP-NETs.

In PanNETs, MEN1, in cooperation with DAXX/ATRX, is probably also involved in chromosome maintenance. PanNETs with mutated MEN1 and DAXX/ATRX are strongly associated with alternative lengthening of telomeres (ALT) and chromosomal instability (Marinoni et al. 2014, Scarpa et al. 2017). This seems not to be the case in BP-NETs, although data correlating MEN1 mutations in TCs and ACs with ALT are lacking (Zaffaroni et al. 2005, Nishio et al. 2007). It was, however, shown that ALT may occur in BP-NECs but not in BP-NETs (Zaffaroni et al. 2005, Nishio et al. 2007).

In PanNETs, the MEN1 mutation in concert with $D A X X / A T R X$ mutations is associated with a PanNET phenotype characterized by an alpha-cell lineage signature (Chan et al. 2018). In this context, it is of interest that glucagon, together with PP and somatostatin, belongs to the most frequently expressed hormones in sporadic PanNETs (Konukiewitz et al. 2020). It is also the most frequent hormone in MEN1 and non-MEN1 microadenomas (Perren et al. 2007, Hermann et al. 2011, Hackeng et al. 2016).

In the group of poorly differentiated NENs, BP-NECs and GEP-NECs frequently share TP53 and RB1 mutations. In BP-NECs, however, RB1 mutations are much more frequent than in GEP-NECs, while TP53 mutations dominate in GEP-NECs (Jesinghaus et al. 2017, Konukiewitz et al. 2017, Simbolo et al. 2017, Konukiewitz et al. 2018). Recently, the genetic profiles of the two subtypes of BP-NECs, small cell and large cell NEC, were compared with each other and also with that of BP-NETs, a study which is so far missing in GEP-NECs, simply because the number of NECs, particular of small cell NECs, is much greater in the BP-system than in the GEP-system. SCLCs, which are morphologically rather homogeneous, are characterized by both TP53 and RB1 alterations in over $90 \%$ of the cases. LCNECs, in contrast, show heterogeneous phenotypical features and are also genotypically heterogeneous (George et al. 2015, 2018, Rekhtman et al. 2016, Derks et al. 2018b). About 40\% of LCNECs share the genetic profile with SCLCs (TP53/ RB1 co-alteration, MYCL1 and SOX2 amplification) and show in $72 \%$ SCLC-like morphology (Rekhtman et al. 2016). Rekhtman et al. called these neoplasms SCLC-type LCNECs (Rekhtman et al. 2016). George et al. studied BP-NECs and called LCNECs with genetic similarity to SCLCs type II LCNECs, emphasizing that in addition to TP53/RB1 co-alterations the type II LCNECs are characterized by elevated expression of genes associated with active Notch signaling (George et al. 2018). The other fraction of the LCNECs mostly lack $R B 1$ mutation and frequently share gene abnormalities of STK11, KRAS, KEAP1 and NKX-2, which are observed in non-small cell lung carcinomas (NSCLCs), particularly of adenocarcinoma type (Rekhtman et al. 2016, 2018, Derks et al. 2018b, George et al. 2018). These LCNECs often present an 'NSCLC-spectrum' morphology (Rekhtman et al. 2016, 2018). It is likely that the LCNECs with NSCLC-spectrum morphology relate to the group of combined LCNECs
(C) 2020 Society for Endocrinology Published by Bioscientifica Ltd. Printed in Great Britain 
(see terminology and grading), which are phenotypically defined by a neuroendocrine carcinoma admixed most frequently with an adenocarcinoma or squamous cell carcinoma. Miyoshi et al. found KRAS mutation in 1 of 10 combined LCNECs in both the neuroendocrine and the adenocarcinoma component (Miyoshi et al. 2017). Rekhtman stained 112 LCNECs with napsin A, an adenocarcinoma marker, and found napsin A positivity in 17 of them. Molecular analysis of 14 out of 17 tumors revealed mutations of KRAS, STK11 or both in 36, 29 and $14 \%$ of the tumors, respectively (Rekhtman et al. 2018). These observations correspond to data in MiNENs and large cell NECs of the colon and the pancreas, which frequently were found to have gene alterations of the respective conventional adenocarcinomas such as KRAS (22-42\%), BRAF (8-33\%) and APC (8-30\%) (Jesinghaus et al. 2017, Konukiewitz et al. 2018). MiNENs and combined BP-NENs also showed monoclonality, when exocrine and endocrine components could be separately examined (Jesinghaus et al. 2017, Miyoshi et al. 2017). The genetic relationship of MiNEN and combined LCNEC suggest that a fraction of conventional adenocarcinomas of the lung, colon and pancreas may undergo neuroendocrine differentiation. In this context, it is also interesting that $3-10 \%$ of lung adenocarcinoma patients, who show T790M mutation after acquired resistance to EGFR tyrosine kinase inhibitor treatment, develop BP-NECs of the small cell type (Derks et al. 2018a).

Many NETs and NECs are clearly separated by their morphology and also by their molecular alterations, as has been demonstrated in Asiedu's transcriptomic analysis (Asiedu et al. 2018). However, some rare cases of NET G3 seem to progress to a NEC-like NEN, driven by a TP53 mutation. In the pancreas, this was observed in one out of nine NETs G3 (Konukiewitz et al. 2018). In the lung, Simbolo identified three BP-NEN clusters using next-generation sequencing. The first cluster included ACs characterized by TP53WT, RB1 ${ }^{\mathrm{WT}}$, and MEN1 ${ }^{\mathrm{mut}}$. The second cluster included LCNECs showing TP53 $3^{\mathrm{mut}}, R B 1^{\mathrm{mut}}$ and MEN1 ${ }^{\mathrm{wt}}$ profile. The third cluster included ACs and LCNECs with TP53mut in $41 \%, M E N 1^{\text {mut }}$ in $23 \%$ and $R B 1^{\text {mut }}$ in $18 \%$ (Simbolo et al. 2019). The patients in the latter cluster with tumors genetically in-between ACs and LCNECs also had a clinical course in-between the other clusters (Simbolo et al. 2019). These tumors appear to be similar to 6 BP-NETs reported by Alcala et al. and called 'supra-carcinoid' (Alcala et al. 2019) and 3 (either with TP53 or Rb1 mutation) of the 11 BP-NETs reported by Cros et al. as high-grade pulmonary carcinoid (Cros et al. 2020). In two of the three studies discussed previously, it is difficult to relate the genetic subclassification to the morphological features of the respective neoplasms, since no subtle description is provided (Alcala et al. 2019, Simbolo et al. 2019). In the study by Cros, at least $70 \%$ of the neoplasms appeared to have a high cellularity, diffuse pattern and slightly pleomorphic nuclei (Cros et al. 2020), making them comparable to the BP-NETs G3 described by us (Kasajima et al. 2019). It seems that also some of the BP-NENs assembled in the complex study of Pelosi et al. belong to the previously discussed NET subgroup that genetically acquires a NEC-like profile in the course of the disease (Pelosi et al. 2018). Since evidence of a clear-cut morphological transition from so-called well-differentiated BP-NENs to poorly differentiated BP-NENs is so far lacking, the NET to NEC transformation hypothesis needs to be further studied in a phenotypically and genotypically integrated analysis.

As the genetic features of BP-NENs underpin the classification of BP-NENs, they are summarized in Fig. 1.

Within the genetic landscape of GEP-NETs, the genetic profile of the NETs of the ileum is unique and also not comparable to that of the BP-NETs. In ileal NETs, somatic mutations are rare and mainly concern the CDKN1B gene. Driver mutations are missing (Karpathakis et al. 2016). Frequent, however, are chromosome 18 deletions seen in $60-90 \%$ of the cases, and epigenetic changes (Karpathakis et al. 2016). Subtyping the molecular profile of ileal NETs revealed three prognostically different subgroups (Karpathakis et al. 2016). Favorable prognosis was associated with chromosome 18 loss and CpG islet methylator phenotype negativity and CDKN1B mutation. CpG islet methylator phenotype positivity and no wholearm copy-number variation were related to intermediate prognosis, while multiple whole-arm copy-number variation correlated with poor prognosis. The special constellation of the ileal NETs is complemented by the near absence of ileal NECs, a feature that they share with appendiceal NENs.

\section{Molecular therapeutical targets}

The major morphological, endocrinological and molecular similarities between BP- and GEP-NENs explain their comparable response to a common multi-disciplinary therapy, including everolimus, somatostatin analogues, chemotherapeutics and peptide receptor radionuclides (PRRT) (Pavel et al. 2016, Yao et al. 2016). With respect to PRRT using ${ }^{117} \mathrm{Lu}$-DOTATATE, which seems to be the most favorable treatment in metastasized or inoperable GEPand BP-NETs that express SSTs (Brabander et al. 2017). 


\section{EN Poorly differentiated NEN}

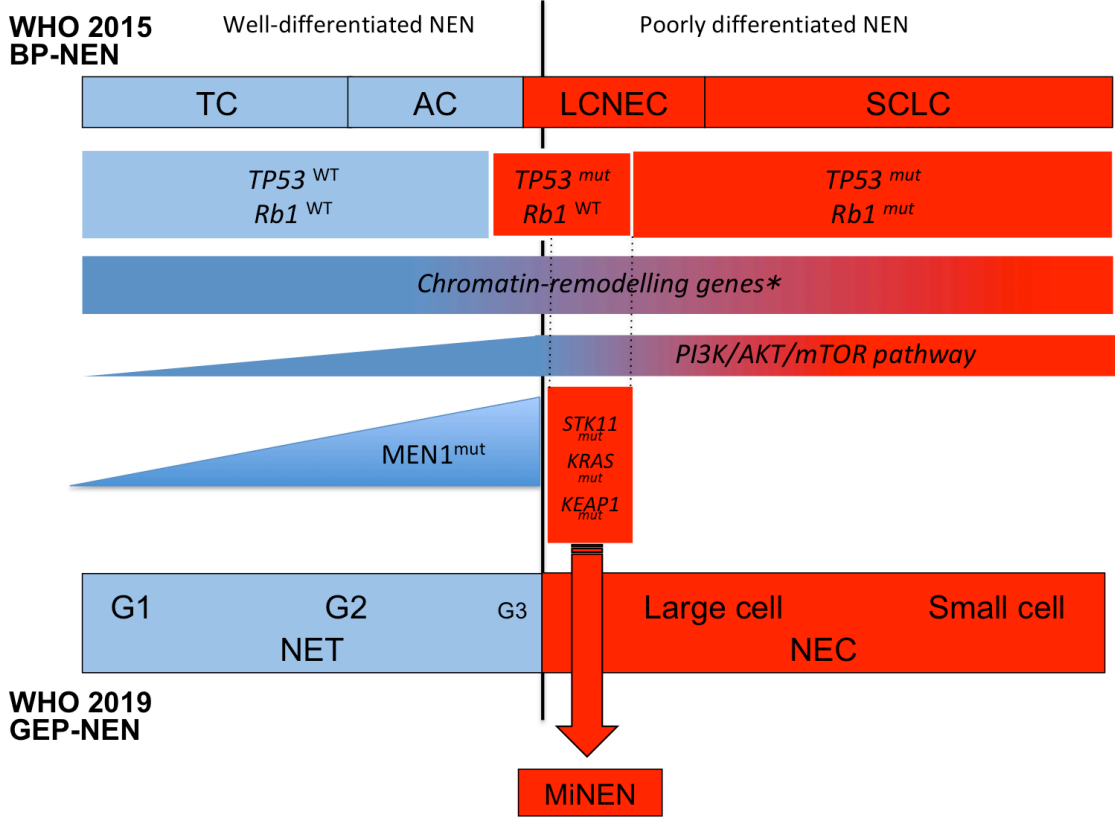

\section{Figure 1}

WHO 2015 classification of bronchopulmonary neuroendocrine neoplasms (BP-NENs) related to the main genetic changes in carcinoids and neuroendocrine carcinomas (NEC), and compared to WHO 2019 classification of gastroenteropancreatic neuroendocrine neoplasms (GEP-NENs). TC, typical carcinoid; AC, atypical carcinoid; LCNEC, large cell

neuroendocrine carcinoma; SCLC, small cell lung carcinoma; NET, neuroendocrine tumor; MiNEN, mixed neuroendocrine non-neuroendocrine neoplasm. *ARID, EIF1AX and KMT2 family. Data extracted from: Rekhtman et al. (2016), Simbolo et al. (2017), Derks et al. (2018a,b), George et al. (2018), Rekhtman et al. (2018), Alcala et al. (2019) \& Simbolo et al. (2019).
It was shown that the overall survival was shorter in BP-NETs (52 months) compared to Pan- and MidgutNETs (71 and 60 months) (Brabander et al. 2017). A better overall survival in Pan- and Midgut-NENs compared to BP-NENs was also shown in the study by Baum et al. (2018), although the survival difference was not as significant as in the aforementioned study, probably because Baum's study included NENs of all grades and not only NETs (Naraev et al. 2019). Why BP-NETs and GEP-NETs obviously have different PRRT response rates, is not known so far.

Approved drugs targeted to specific molecular structures are so far few and concentrate on everolimus, an inhibitor of the $m T O R / A K T / P I K 3 C A$ signaling pathway (Derks et al. 2018a). The disadvantage of this inhibitor, however, is that biomarkers predicting its response have not yet been established. Moreover, the mTOR/AKT/ PIK3CA gene alterations were only found in a rather small number of patients, accounting for $2-12 \%$ and $15 \%$ BPand PanNET patients, respectively (Scarpa et al. 2017, Simbolo et al. 2017).

Agents specifically targeted to EGFR, KRAS, BRAF and other adenocarcinoma related gene targets (i.e. EML4/ ALK, ROS1) (see also Derks et al. 2018a) are of special interest for the treatment of MiNENs, because molecular studies in MiNENs and conventional adenocarcinomas of the colon revealed a close genetic relationship between these tumors (Jesinghaus et al. 2017). A similar genetic relationship was also found in the BP-system between LCNECs and adenocarcinomas as well as squamous cell carcinomas (Rekhtman et al. 2016).

(c) 2020 Society for Endocrinology Published by Bioscientifica Ltd. Printed in Great Britain
In SCLCs, DLL3, which is an inhibitory ligand of the NOTCH pathway, was found to be expressed. Treatment with a DLL3-targeted antibody conjugated to a DNA-damaging pryrolobenzodiazepine dimer doxin induced durable regression in patient-derived xenograft tumors (Derks et al. 2018a), but phase III clinical trials (NCT03061812, NCT03033511) failed to show any survival benefit for the patients. Currently DLL3 targeting chimeric antigen receptor $\mathrm{T}$ cell therapy (CAR-T) AMG 119 (NCT03392064) is tested (Isobe et al. 2020).

\section{Prognostic molecular factors}

A wide-range of prognostic molecular factors has been reported in BP-NENs and GEP-NENs. The most important molecular prognostic factors are listed in Table 6.

\section{Conclusions}

BP-NENs and GEP-NENs have a common phenotype and genotype, however, with some notable exceptions. Common to both is a general morphological and genetical dichotomy in well- and poorly differentiated neoplasms, whose proliferative activity can be well depicted in a Ki67-based grading system with strong prognostic implications. This grading system is well established for the stratifications of GEP-NENs, while it has to be fully validated in BP-NENs. This also applies to 
Table 6 Dismal molecular prognostic factors in bronchopulmonary and gastroenteropancreatic neuroendocrine neoplasms (BP-NENs and GEP-NENs).

\begin{tabular}{|c|c|}
\hline & Prognostic factors \\
\hline \multirow[t]{4}{*}{ BP-NENS } & MEN1 deletion \\
\hline & Low CD44, OTP expression \\
\hline & TERT gain \\
\hline & Rb1 mutation \\
\hline \multirow[t]{8}{*}{ GEP-NENs } & PTEN loss \\
\hline & PgR loss \\
\hline & Aneuploidy \\
\hline & CK19 expression \\
\hline & KIT expression \\
\hline & Loss of heterozygosity at $1 p, 3 p, 6 q, 17 p, 22 q$ and $X$ \\
\hline & Low DAXX/ATRX Expression. ALT activation \\
\hline & $\begin{array}{l}\text { CpG islet methylator phenotype positivity and } \\
\text { multiple whole-arm copy-number variation }\end{array}$ \\
\hline
\end{tabular}

\begin{tabular}{l}
\hline Study cohort \\
\hline 55 NETs (stage not given) \\
108 NETs (55\% pT1, 75\% pN0) \\
88 NETs (72\% Stage I) \\
60 NECs (22\% Stage I) \\
160 PanNETs (25\% Stage I) \\
27 PanNETs (stage not given) \\
216 PanNETs (surgically resected; stage \\
not given) \\
97 PanNETs (surgically resected; 50\% N0M0) \\
34 PanNETs (stage not given) \\
321 PanNETs (36\% pT1, 63\% pN0) \\
243 PanNETs (67\% M0) \\
97 SI-NETs (25\% M1)
\end{tabular}

\section{Reference \\ Swarts et al. 2014 \\ Papaxoinis et al. 2017 \\ Simbolo et al. 2017 \\ Estrella et al. 2014}

Donow et al. 1991

Schmitt et al. 2007

Zhang et al. 2009

Pizzi et al. 2002

Singhi et al. 2017

Marinoni et al. 2014

Karpathakis et al. 2016

BP-NEN, bronchopulmonary neuroendocrine neoplasm; GEP-NEN, gastroenteropancreatic neuroendocrine neoplasm; NEC, neuroendocrine carcinoma; NET, neuroendocrine tumor; OTP, orthopedia homebox; PanNET, pancreatic neuroendocrine tumor; PgR, progesteron receptor; SI-NET, small intestine neuroendocrine tumor.

the new category of NET G3 identified in the GEP-system. Whether all NETs G3 remain genetically different from NECs or evolve in some cases to NECs by additional genetic changes, such as TP53 mutations, has to be clarified in future studies. Differences between BP-NETs and GEP-NETs mainly concern the hormonal composition of the tumors and the pathogenetic role of the MEN1 gene. Other differences focus on the large cell subgroup of NECs and its heterogeneous genetic profile, which partly shows a site-specific relationship to the main genetic abnormalities of the respective conventional carcinomas. Future classifications of BP- and GEP-NENs should consider the great commonalities between the two most important NEN groups of the body regarding terminology and grading but also allow to categorize the neoplasms according to the most obvious and therapy relevant sitespecific differences.

\section{Declaration of interest}

The authors declare that there is no conflict of interest that could be perceived as prejudicing the impartiality of this review.

\section{Funding}

This work did not receive any specific grant from any funding agency in the public, commercial or not-profit sector.

\section{Author contribution statement}

Both authors contributed to designing and writing this review article.

\section{References}

Agaimy A, Erlenbach-Wunsch K, Konukiewitz B, Schmitt AM, Rieker RJ, Vieth M, Kiesewetter F, Hartmann A, Zamboni G, Perren A, et al. 2013 ISL1 expression is not restricted to pancreatic welldifferentiated neuroendocrine neoplasms, but is also commonly found in well and poorly differentiated neuroendocrine neoplasms of extrapancreatic origin. Modern Pathology 26 995-1003. (https:// doi.org/10.1038/modpathol.2013.40)

Alcala N, Leblay N, Gabriel AAG, Mangiante L, Hervas D, Giffon T, Sertier AS, Ferrari A, Derks J, Ghantous A, et al. 2019 Integrative and comparative genomic analyses identify clinically relevant pulmonary carcinoid groups and unveil the supra-carcinoids. Nature Communications 10 3407. (https://doi.org/10.1038/s41467-019-11276-9)

Anlauf M, Schlenger R, Perren A, Bauersfeld J, Koch CA, Dralle H, Raffel A, Knoefel WT, Weihe E, Ruszniewski P, et al. 2006 Microadenomatosis of the endocrine pancreas in patients with and without the multiple endocrine neoplasia type 1 syndrome. American Journal of Surgical Pathology 30 560-574. (https://doi.org/10.1097/01. pas.0000194044.01104.25)

Arrigoni MG, Woolner LB \& Bernatz PE 1972 Atypical carcinoid tumors of the lung. Journal of Thoracic and Cardiovascular Surgery 64 413-421. (https://doi.org/10.1016/SO022-5223(19)39836-8)

Asiedu MK, Thomas CF, Jr, Dong J, Schulte SC, Khadka P, Sun Z, Kosari F, Jen J, Molina J, Vasmatzis G, et al. 2018 Pathways impacted by genomic alterations in pulmonary carcinoid tumors. Clinical Cancer Research 24 1691-1704. (https://doi.org/10.1158/1078-0432.CCR-17-0252)

Bari MF, Brown H, Nicholson AG, Kerr KM, Gosney JR, Wallace WA, Soomro I, Muller S, Peat D, Moore JD, et al. 2014 BAI3, CDX2 and VIL1: a panel of three antibodies to distinguish small cell from large cell neuroendocrine lung carcinomas. Histopathology 64 547-556. (https://doi.org/10.1111/his.12278)

Bartsch DK, Albers MB, Lopez CL, Apitzsch JC, Walthers EM, Fink L, Fendrich V, Slater EP, Waldmann J \& Anlauf M 2016 Bronchopulmonary neuroendocrine neoplasms and their precursor lesions in multiple endocrine neoplasia Type 1. Neuroendocrinology 103 240-247. (https://doi.org/10.1159/000435921)

Baum RP, Kulkarni HR, Singh A, Kaemmerer D, Mueller D, Prasad V, Hommann M, Robiller FC, Niepsch K, Franz H, et al. 2018 Results and adverse events of personalized peptide receptor radionuclide https://erc.bioscientifica.com

https://doi.org/10.1530/ERC-20-0122
(C) 2020 Society for Endocrinology Published by Bioscientifica Ltd. Printed in Great Britain 
therapy with (90). Oncotarget 9 16932-16950. (https://doi. org/10.18632/oncotarget.24524)

Bonato M, Cerati M, Pagani A, Papotti M, Bosi F, Bussolati G \& Capella C 1992 Differential diagnostic patterns of lung neuroendocrine tumours. A clinico-pathological and immunohistochemical study of 122 cases. Virchows Archiv: A, Pathological Anatomy and Histopathology 420 201-211. (https://doi. org/10.1007/BF01600272)

Bosman F, Camerio F, Hruban R \& Theise N 2010 WHO Classification of Tumours of the Digestive System. Lyon, France: IARC Press.

Brabander T, van der Zwan WA, Teunissen JJM, Kam BLR, Feelders RA, de Herder WW, van Eijck CHJ, Franssen GJH, Krenning EP \& Kwekkeboom DJ 2017 Long-term efficacy, survival, and safety of [(177)Lu-DOTA(0),Tyr(3)]octreotate in patients with gastroenteropancreatic and bronchial neuroendocrine tumors. Clinical Cancer Research 23 4617-4624. (https://doi. org/10.1158/1078-0432.CCR-16-2743)

Brambilla E, Beasley MB, Austin JHM, Capelozzi VL, Chirieac LR, Devesa SS, Frank GA, Gazdar A, Ishikawa Y, Jen J, et al. 2015 Neuroendocrine tumours. In WHO Classification of Tumours of the Lung, Pleura, Thymus and Heart, 4th ed., pp. 63-78. Lyon, France: IARC Press.

Capella C, Heitz PU, Höfler H, Solcia E \& Klöppel G 1995 Revised classification of neuroendocrine tumours of the lung, pancreas and gut. Virchows Archiv: A, Pathological Anatomy and Histopathology 425 547-560. (https://doi.org/10.1007/BF00199342)

Chan ES, Alexander J, Swanson PE, Jain D \& Yeh MM 2012 PDX-1, CDX-2, TTF-1, and CK7: a reliable immunohistochemical panel for pancreatic neuroendocrine neoplasms. American Journal of Surgical Pathology 36 737-743. (https://doi.org/10.1097/ PAS.0b013e31824aba59)

Chan CS, Laddha SV, Lewis PW, Koletsky MS, Robzyk K, Da Silva E, Torres PJ, Untch BR, Li J, Bose P, et al. 2018 ATRX, DAXX or MEN1 mutant pancreatic neuroendocrine tumors are a distinct alpha-cell signature subgroup. Nature Communications 9 4158. (https://doi. org/10.1038/s41467-018-06498-2)

Cros J, Theou-Anton N, Gounant V, Nicolle R, Reyes C, Humez S, Hescot S, Thomas de Montpreville V, Guyetant S, Scoazec JY, et al. 2020 Specific genomic alterations in high grade pulmonary neuroendocrine tumours with carcinoid morphology. Neuroendocrinology [epub]. (https://doi.org/10.1159/000506292)

Daddi N, Schiavon M, Filosso PL, Cardillo G, Ambrogi MC, De Palma A, Luzzi L, Bandiera A, Casali C, Ruffato A, et al. 2014 Prognostic factors in a multicentre study of 247 atypical pulmonary carcinoids. European Journal of Cardio-Thoracic Surgery 45 677-686. (https://doi. org/10.1093/ejcts/ezt470)

Dasari A, Mehta K, Byers LA, Sorbye H \& Yao JC 2018 Comparative study of lung and extrapulmonary poorly differentiated neuroendocrine carcinomas: a SEER database analysis of 162,983 cases. Cancer 124 807-815. (https://doi.org/10.1002/cncr.31124)

Daskalakis K, Chatzelis E, Tsoli M, Papadopoulou-Marketou N, Dimitriadis GK, Tsolakis AV \& Kaltsas G 2019 Endocrine paraneoplastic syndromes in patients with neuroendocrine neoplasms. Endocrine 64 384-392. (https://doi.org/10.1007/s12020-018-1773-3)

de Laat JM, Pieterman CR, van den Broek MF, Twisk JW, Hermus AR, Dekkers OM, de Herder WW, van der Horst-Schrivers AN, Drent ML, Bisschop PH, et al. 2014 Natural course and survival of neuroendocrine tumors of thymus and lung in MEN1 patients. Journal of Clinical Endocrinology and Metabolism 99 3325-3333. (https://doi.org/10.1210/jc.2014-1560)

Derks JL, Leblay N, Lantuejoul S, Dingemans AC, Speel EM \& FernandezCuesta L 2018a New insights into the molecular characteristics of pulmonary carcinoids and large cell neuroendocrine carcinomas, and the impact on their clinical management. Journal of Thoracic Oncology 13 752-766. (https://doi.org/10.1016/j.jtho.2018.02.002)

Derks JL, Leblay N, Thunnissen E, van Suylen RJ, den Bakker M, Groen HJM, Smit EF, Damhuis R, van den Broek EC, Charbrier A, et al. 2018b Molecular subtypes of pulmonary large-cell neuroendocrine carcinoma predict chemotherapy treatment outcome. Clinical Cancer Research 24 33-42. (https://doi. org/10.1158/1078-0432.CCR-17-1921)

Dinter H, Bohnenberger H, Beck J, Bornemann-Kolatzki K, Schutz E, Kuffer S, Klein L, Franks TJ, Roden A, Emmert A, et al. 2019 Molecular classification of neuroendocrine tumors of the thymus. Journal of Thoracic Oncology 14 1472-1483. (https://doi.org/10.1016/j. jtho.2019.04.015)

Donow C, Baisch H, Heitz PU \& Klöppel G 1991 Nuclear DNA content in 27 pancreatic endocrine tumours: correlation with malignancy, survival and expression of glycoprotein hormone alpha chain. Virchows Archiv: A, Pathological Anatomy and Histopathology 419 463-468. (https://doi.org/10.1007/BF01650673)

Estrella JS, Broaddus RR, Mathews A, Milton DR, Yao JC, Wang H \& Rashid A 2014 Progesterone receptor and PTEN expression predict survival in patients with low- and intermediate-grade pancreatic neuroendocrine tumors. Archives of Pathology and Laboratory Medicine 138 1027-1036. (https://doi.org/10.5858/arpa.20130195-OA)

Fernandez-Cuesta L, Peifer M, Lu X, Sun R, Ozretic L, Seidal D, Zander T, Leenders F, George J, Muller C, et al. 2014 Frequent mutations in chromatin-remodelling genes in pulmonary carcinoids. Nature Communications 5 3518. (https://doi.org/10.1038/ncomms4518)

Frizziero M, Wang X, Chakrabarty B, Childs A, Luong TV, Walter T, Khan MS, Morgan M, Christian A, Elshafie M, et al. 2019 Retrospective study on mixed neuroendocrine non-neuroendocrine neoplasms from five European centres. World Journal of Gastroenterology 25 5991-6005. (https://doi.org/10.3748/wjg.v25.i39.5991)

Fujino K, Motooka Y, Hassan WA, Ali Abdalla MO, Sato Y, Kudoh S, Hasegawa K, Niimori-Kita K, Kobayashi H, Kubota I, et al. 2015 Insulinoma-associated protein 1 is a crucial regulator of neuroendocrine differentiation in lung cancer. American Journal of Pathology 1853164 3177. (https://doi.org/10.1016/j.ajpath.2015.08.018)

Garbrecht N, Anlauf M, Schmitt A, Henopp T, Sipos B, Raffel A, Eisenberger CF, Knoefel WT, Pavel M, Fottner C, et al. 2008 Somatostatin-producing neuroendocrine tumors of the duodenum and pancreas: incidence, types, biological behavior, association with inherited syndromes, and functional activity. Endocrine-Related Cancer 15 229-241. (https://doi.org/10.1677/ERC-07-0157)

George J, Lim JS, Jang SJ, Cun Y, Ozretic L, Kong G, Leenders F, Lu X, Fernandez-Cuesta L, Bosco G, et al. 2015 Comprehensive genomic profiles of small cell lung cancer. Nature $\mathbf{5 2 4} 47-53$. (https://doi. org/10.1038/nature14664)

George J, Walter V, Peifer M, Alexandrov LB, Seidel D, Leenders F, Maas L, Muller C, Dahmen I, Delhomme TM, et al. 2018 Integrative genomic profiling of large-cell neuroendocrine carcinomas reveals distinct subtypes of high-grade neuroendocrine lung tumors. Nature Communications 9 1048. (https://doi.org/10.1038/s41467-018-03099-x)

Goudet P, Bonithon-Kopp C, Murat A, Ruszniewski P, Niccoli P, Menegaux F, Chabrier G, Borson-Chazot F, Tabarin A, Bouchard P, et al. 2011 Gender-related differences in MEN1 lesion occurrence and diagnosis: a cohort study of 734 cases from the Groupe d'Etude des Tumeurs Endocrines. European Journal of Endocrinology 165 97-105. (https://doi.org/10.1530/EJE-10-0950)

Granberg D, Wilander E, Oberg K \& Skogseid B 2000 Prognostic markers in patients with typical bronchial carcinoid tumors. Journal of Clinical Endocrinology and Metabolism 85 3425-3430.

Gustafsson BI, Kidd M, Chan A, Malfertheiner MV \& Modlin IM 2008 Bronchopulmonary neuroendocrine tumors. Cancer 113 5-21. (https://doi.org/10.1002/cncr.23542)

Hackeng WM, Brosens LA, Poruk KE, Noe M, Hosoda W, Poling JS, Rizzo A, Campbell-Thompson M, Atkinson MA, Konukiewitz B, et al. 2016 Aberrant menin expression is an early event in pancreatic neuroendocrine tumorigenesis. Human Pathology 56 93-100. (https:// doi.org/10.1016/j.humpath.2016.06.006) 
Halperin DM, Shen C, Dasari A, Xu Y, Chu Y, Zhou S, Shih YT \& Yao JC 2017 Frequency of carcinoid syndrome at neuroendocrine tumour diagnosis: a population-based study. Lancet: Oncology 18 525-534. (https://doi.org/10.1016/S1470-2045(17)30110-9)

Hamperl H 1937 Über gutartige bronchialtumoren (cylindrome und carcinoide). Virchows Archiv A 300 46-88.

Hayes AR, Banks J, Shah H, Luong TV, Navalkissoor S, Grossman A, Mandair D, Toumpanakis C \& Caplin M 20181323 P - diffuse idiopathic pulmonary neuroendocrine cell hyperplasia (DIPNECH) in patients with pulmonary carcinoid tumours: prevalence and prognosis of an under-recognised disease. Annals of Oncology 29 viii 474. (https://doi.org/10.1093/annonc/mdy293.016)

Hermann G, Konukiewitz B, Schmitt A, Perren A \& Kloppel G 2011 Hormonally defined pancreatic and duodenal neuroendocrine tumors differ in their transcription factor signatures: expression of ISL1, PDX1, NGN3, and CDX2. Virchows Archiv 459 147-154. (https://doi.org/10.1007/s00428-011-1118-6)

Isobe Y, Sato K, Nishinaga Y, Takahashi K, Taki S, Yasui H, Shimizu M, Endo R, Koike C, Kuramoto N, et al. 2020 Near infrared photoimmunotherapy targeting DLL3 for small cell lung cancer. EBiomedicine 52 102632. (https://doi.org/10.1016/j. ebiom.2020.102632)

Jann H, Roll S, Couvelard A, Hentic O, Pavel M, Müller-Nordhorn J, Koch M, Röcken C, Rindi G, Ruszniewski P, et al. 2011 Neuroendocrine tumors of midgut and hindgut origin: tumor-nodemetastasis classification determines clinical outcome. Cancer 117 3332-3341. (https://doi.org/10.1002/cncr.25855)

Jesinghaus M, Konukiewitz B, Keller G, Kloor M, Steiger K, Reiche M, Penzel R, Endris V, Arsenic R, Hermann G, et al. 2017 Colorectal mixed adenoneuroendocrine carcinomas and neuroendocrine carcinomas are genetically closely related to colorectal adenocarcinomas. Modern Pathology 30 610-619. (https://doi. org/10.1038/modpathol.2016.220)

Jiao Y, Shi C, Edil BH, de Wilde RF, Klimstra DS, Maitra A, Schulick RD, Tang LH, Wolfgang CL, Choti MA, et al. 2011 DAXX/ATRX, MEN1, and $\mathrm{mTOR}$ pathway genes are frequently altered in pancreatic neuroendocrine tumors. Science 331 1199-1203. (https://doi. org/10.1126/science.1200609)

Kaemmerer D, Specht E, Sanger J, Wirtz RM, Sayeg M, Schulz S \& Lupp A 2015 Somatostatin receptors in bronchopulmonary neuroendocrine neoplasms: new diagnostic, prognostic, and therapeutic markers. Journal of Clinical Endocrinology and Metabolism 100 831-840. (https://doi.org/10.1210/jc.2014-2699)

Karpathakis A, Dibra H, Pipinikas C, Feber A, Morris T, Francis J, Oukrif D, Mandair D, Pericleous M, Mohmaduvesh M, et al. 2016 Prognostic impact of novel molecular subtypes of small intestinal neuroendocrine tumor. Clinical Cancer Research 22 250-258. (https:// doi.org/10.1158/1078-0432.CCR-15-0373)

Kasajima A, Konukiewitz B, Oka N, Suzuki H, Sakurada A, Okada Y, Kameya T, Ishikawa Y, Sasano H, Weichert W, et al. 2019 Clinicopathological profiling of lung carcinoids with a Ki67 index > 20. Neuroendocrinology 108 109-120. (https://doi. org/10.1159/000495806)

Klimstra D, Klöppel G, La Rosa Salas B \& Rindi G 2019 Classification of neuroendocrine neoplasms of the digestive system. In WHO Classification of Tumours. Digestive System Tumours, 5th ed., pp. 16-21. Lyon, France: IARC Press.

Klöppel G 2017 Neuroendocrine neoplasms: dichotomy, origin and classifications. Visceral Medicine 33 324-330. (https://doi. org/10.1159/000481390)

Klöppel G \& La Rosa S 2018 Ki67 labeling index: assessment and prognostic role in gastroenteropancreatic neuroendocrine neoplasms. Virchows Archiv 472 341-349. (https://doi.org/10.1007/s00428-0172258-0)

Klöppel G, Couvelard A, Hruban R, Klimstra D, Komminoth P, Osamura RY, Perren A \& Rindi G 2017a Neuroendocrine neoplasms of the pancreas. In WHO Classification of Tumours of Endocrine Organs, 4th ed., pp. 210-239. Lyon, France: IARC Press.

Konukiewitz B, Enosawa T \& Klöppel G 2011 Glucagon expression in cystic pancreatic neuroendocrine neoplasms: an immunohistochemical analysis. Virchows Archiv 458 47-53. (https:// doi.org/10.1007/s00428-010-0985-6)

Konukiewitz B, Schlitter AM, Jesinghaus M, Pfister D, Steiger K, Segler A, Agaimy A, Sipos B, Zamboni G, Weichert W, et al. 2017 Somatostatin receptor expression related to TP53 and RB1 alterations in pancreatic and extrapancreatic neuroendocrine neoplasms with a Ki67-index above 20. Modern Pathology 30 587-598. (https://doi.org/10.1038/ modpathol.2016.217)

Konukiewitz B, Jesinghaus M, Steiger K, Schlitter AM, Kasajima A, Sipos B, Zamboni G, Weichert W, Pfarr N \& Klöppel G 2018 Pancreatic neuroendocrine carcinomas reveal a closer relationship to ductal adenocarcinomas than to neuroendocrine tumors G3. Human Pathology 77 70-79. (https://doi.org/10.1016/j.humpath.2018.03.018)

Konukiewitz B, Hornstein MV, Jesinghaus M, Steiger K, Weichert W, Detlefsen S, Kasajima A \& Kloppel G 2020 Pancreatic neuroendocrine tumors with somatostatin expression and paraganglioma-like features. Human Pathology 102 79-87. (https:// doi.org/10.1016/j.humpath.2020.07.004)

La Rosa S, Chiaravalli AM, Placidi C, Papanikolaou N, Cerati M \& Capella C 2010 TTF1 expression in normal lung neuroendocrine cells and related tumors: immunohistochemical study comparing two different monoclonal antibodies. Virchows Archiv 457 497-507. (https://doi.org/10.1007/s00428-010-0954-0)

La Rosa S, Franzi F, Albarello L, Schmitt A, Bernasconi B, Tibiletti MG, Finzi G, Placidi C, Perren A \& Capella C 2011 Serotonin-producing enterochromaffin cell tumors of the pancreas: clinicopathologic study of 15 cases and comparison with intestinal enterochromaffin cell tumors. Pancreas 40 883-895. (https://doi.org/10.1097/ MPA.0b013e31822041a9)

La Rosa S, Sessa F \& Uccella S 2016 Mixed neuroendocrinenonneuroendocrine neoplasms (MiNENs): unifying the concept of a heterogeneous group of neoplasms. Endocrine Pathology 27 284-311. (https://doi.org/10.1007/s12022-016-9432-9)

La Rosa S, Uccella S, Molinari F, Savio A, Mete O, Vanoli A, Maragliano R, Frattini M, Mazzucchelli L, Sessa F, et al. 2018 Mixed adenoma well-differentiated neuroendocrine tumor (MANET) of the digestive system: an indolent subtype of mixed neuroendocrineNonNeuroendocrine neoplasm (MiNEN). American Journal of Surgical Pathology 42 1503-1512. (https://doi.org/10.1097/ PAS.0000000000001123)

La Rosa S, Volante M, Uccella S, Maragliano R, Rapa I, Rotolo N, Inzani F, Siciliani A, Granone P, Rindi G, et al. 2019 ACTH-producing tumorlets and carcinoids of the lung: clinico-pathologic study of 63 cases and review of the literature. Virchows Archiv 475 587-597. (https://doi.org/10.1007/s00428-019-02612-x)

Lee H, Fu Z, Koo BH, Sheehan CE, Young GQ, Lin J, Patil DT \& Yang Z 2018 The expression of TTF1, CDX2 and ISL1 in 74 poorly differentiated neuroendocrine carcinomas. Annals of Diagnostic Pathology 37 30-34. (https://doi.org/10.1016/j.anndiagpath.2018.09.005)

Maragliano R, Vanoli A, Albarello L, Milione M, Basturk O, Klimstra DS, Wachtel A, Uccella S, Vicari E, Milesi M, et al. 2015 ACTH-secreting pancreatic neoplasms associated with Cushing syndrome: clinicopathologic study of 11 cases and review of the literature. American Journal of Surgical Pathology 39 374-382. (https://doi. org/10.1097/PAS.0000000000000340)

Marinoni I, Kurrer AS, Vassella E, Dettmer M, Rudolph T, Banz V, Hunger F, Pasquinelli S, Speel EJ \& Perren A 2014 Loss of DAXX and ATRX are associated with chromosome instability and reduced survival of patients with pancreatic neuroendocrine tumors. Gastroenterology 146 453.e5-460.e5. (https://doi.org/10.1053/j.gastro.2013.10.020)

McCall CM, Shi C, Klein AP, Konukiewitz B, Edil BH, Ellison TA, Wolfgang CL, Schulick RD, Klöppel G \& Hruban RH 2012 Serotonin https://erc.bioscientifica.com

https://doi.org/10.1530/ERC-20-0122 (c) 2020 Society for Endocrinology Published by Bioscientifica Ltd. Printed in Great Britain 
expression in pancreatic neuroendocrine tumors correlates with a trabecular histologic pattern and large duct involvement. Human Pathology 43 1169-1176. (https://doi.org/10.1016/j. humpath.2011.09.014)

Mengoli MC, Rossi G, Cavazza A, Franco R, Marino FZ, Migaldi M, Gnetti L, Silini EM, Ampollini L, Tiseo M, et al. 2018 Diffuse idiopathic pulmonary neuroendocrine cell hyperplasia (DIPNECH) syndrome and carcinoid tumors with/without NECH: a clinicopathologic, radiologic, and immunomolecular comparison study. American Journal of Surgical Pathology 42 646-655. (https://doi. org/10.1097/PAS.0000000000001033)

Miyoshi T, Umemura S, Matsumura Y, Mimaki S, Tada S, Makinoshima H, Ishii G, Udagawa H, Matsumoto S, Yoh K, et al. 2017 Genomic profiling of large-cell neuroendocrine carcinoma of the lung. Clinical Cancer Research 23 757-765. (https://doi. org/10.1158/1078-0432.CCR-16-0355)

Moonen L, Derks J, Dingemans AM \& Speel EJ 2019 Orthopedia homeobox (OTP) in pulmonary neuroendocrine tumors: the diagnostic value and possible molecular interactions. Cancers $\mathbf{1 1}$ 1508. (https://doi.org/10.3390/cancers11101508)

Naheed S, Holden C, Tanno L, Jaynes E, Cave J, Ottensmeier CH \& Pelosi G 2019 The utility of Ki-67 as a prognostic biomarker in pulmonary neuroendocrine tumours: protocol for a systematic review and meta-analysis. BMJ Open 9 e031531. (https://doi. org/10.1136/bmjopen-2019-031531)

Naraev BG, Ramirez RA, Kendi AT \& Halfdanarson TR 2019 Peptide receptor radionuclide therapy for patients with advanced lung carcinoids. Clinical Lung Cancer 20 e376-e392. (https://doi. org/10.1016/j.cllc.2019.02.007)

Nishio Y, Nakanishi K, Ozeki Y, Jiang SX, Kameya T, Hebisawa A, Mukai M, Travis WD, Franks TJ \& Kawai T 2007 Telomere length, telomerase activity, and expressions of human telomerase mRNA component (hTERC) and human telomerase reverse transcriptase (hTERT) mRNA in pulmonary neuroendocrine tumors. Japanese Journal of Clinical Oncology 37 16-22. (https://doi.org/10.1093/jjco/hyl118)

Nozieres C, Chardon L, Goichot B, Borson-Chazot F, Hervieu V, Chikh K, Lombard-Bohas C \& Walter T 2016 Neuroendocrine tumors producing calcitonin: characteristics, prognosis and potential interest of calcitonin monitoring during follow-up. European Journal of Endocrinology 174 335-341. (https://doi. org/10.1530/EJE-15-0917)

Oka N, Kasajima A, Konukiewitz B, Sakurada A, Okada Y, Kameya T, Weichert W, Ishikawa Y, Suzuki H, Sasano H, et al. 2020 Classification and prognostic stratification of bronchopulmonary neuroendocrine neoplasms. Neuroendocrinology 110 393-403. (https://doi.org/10.1159/000502776)

Papaxoinis G, Nonaka D, O’Brien C, Sanderson B, Krysiak P \& Mansoor W 2017 Prognostic significance of CD44 and orthopedia homeobox protein (OTP) expression in pulmonary carcinoid tumours. Endocrine Pathology 28 60-70. (https://doi.org/10.1007/ s12022-016-9459-y)

Pape UF, Jann H, Muller-Nordhorn J, Bockelbrink A, Berndt U, Willich SN, Koch M, Rocken C, Rindi G \& Wiedenmann B 2008 Prognostic relevance of a novel TNM classification system for upper gastroenteropancreatic neuroendocrine tumors. Cancer 113 256-265 (https://doi.org/10.1002/cncr.23549)

Pavel M, O'Toole D, Costa F, Capdevila J, Gross D, Kianmanesh R, Krenning E, Knigge U, Salazar R, Pape UF, et al. 2016 Enets consensus guidelines update for the management of distant metastatic disease of intestinal, pancreatic, bronchial neuroendocrine neoplasms (NEN) and NEN of unknown primary site. Neuroendocrinology 103 172-185. (https://doi.org/10.1159/000443167)

Pelosi G, Bianchi F, Dama E, Simbolo M, Mafficini A, Sonzogni A, Pilotto S, Harari S, Papotti M, Volante M, et al. 2018 Most high-grade neuroendocrine tumours of the lung are likely to secondarily develop from pre-existing carcinoids: innovative findings skipping the current pathogenesis paradigm. Virchows Archiv 472 567-577. (https://doi.org/10.1007/s00428-018-2307-3)

Perigny M, Hammel P, Corcos O, Larochelle O, Giraud S, Richard S, Sauvanet A, Belghiti J, Ruszniewski P, Bedossa P, et al. 2009 Pancreatic endocrine microadenomatosis in patients with von Hippel-Lindau disease: characterization by VHL/HIF pathway proteins expression. American Journal of Surgical Pathology 33 739-748. (https://doi.org/10.1097/PAS.0b013e3181967992)

Perren A, Anlauf M, Henopp T, Rudolph T, Schmitt A, Raffel A, Gimm O, Weihe E, Knoefel WT, Dralle H, et al. 2007 Multiple endocrine neoplasia type 1 (MEN1): loss of one MEN1 allele in tumors and monohormonal endocrine cell clusters but not in islet hyperplasia of the pancreas. Journal of Clinical Endocrinology and Metabolism 92 1118-1128. (https://doi.org/10.1210/jc.2006-1944)

Pizzi S, D'Adda T, Azzoni C, Rindi G, Grigolato P, Pasquali C, Corleto VD, Delle Fave G \& Bordi C 2002 Malignancy-associated allelic losses on the $\mathrm{X}$-chromosome in foregut but not in midgut endocrine tumours. Journal of Pathology 196 401-407. (https://doi. org/10.1002/path.1075)

Qin J \& Lu H 2018 Combined small-cell lung carcinoma. OncoTargets and Therapy 11 3505-3511. (https://doi.org/10.2147/OTT.S159057)

Quinn AM, Chaturvedi A \& Nonaka D 2017 High-grade neuroendocrine carcinoma of the lung With carcinoid morphology: a study of 12 cases. American Journal of Surgical Pathology 41 263-270. (https://doi. org/10.1097/PAS.0000000000000767)

Rekhtman N, Pietanza MC, Hellmann MD, Naidoo J, Arora A, Won H, Halpenny DF, Wang H, Tian SK, Litvak AM, et al. 2016 Nextgeneration sequencing of pulmonary large cell neuroendocrine carcinoma reveals small cell carcinoma-like and non-small cell carcinoma-like subsets. Clinical Cancer Research 22 3618-3629. (https://doi.org/10.1158/1078-0432.CCR-15-2946)

Rekhtman N, Pietanza CM, Sabari J, Montecalvo J, Wang H, Habeeb O, Kadota K, Adusumilli P, Rudin CM, Ladanyi M, et al. 2018 Pulmonary large cell neuroendocrine carcinoma with adenocarcinoma-like features: napsin A expression and genomic alterations. Modern Pathology 31 111-121. (https://doi.org/10.1038/ modpathol.2017.110)

Rekhtman N, Desmeules P, Litvak AM, Pietanza MC, Santos-Zabala ML, Ni A, Montecalvo J, Chang JC, Beras A, Preeshagul IR, et al. 2019 Stage IV lung carcinoids: spectrum and evolution of proliferation rate, focusing on variants with elevated proliferation indices. Modern Pathology 32 1106-1122. (https://doi.org/10.1038/s41379-019-0248-2)

Righi L, Volante M, Tavaglione V, Bille A, Daniele L, Angusti T, Inzani F, Pelosi G, Rindi G \& Papotti M 2010 Somatostatin receptor tissue distribution in lung neuroendocrine tumours: a clinicopathologic and immunohistochemical study of 218 'clinically aggressive' cases. Annals of Oncology 21 548-555. (https://doi.org/10.1093/annonc/mdp334)

Rindi G, Klersy C, Inzani F, Fellegara G, Ampollini L, Ardizzoni A, Campanini N, Carbognani P, De Pas TM, Galetta D, et al. 2014 Grading the neuroendocrine tumors of the lung: an evidence-based proposal. Endocrine-Related Cancer 21 1-16. (https://doi.org/10.1530/ ERC-13-0246)

Rindi G, Klersy C, Albarello L, Baudin E, Bianchi A, Buchler MW, Caplin M, Couvelard A, Cros J, de Herder WW, et al. 2018a Competitive testing of the WHO 2010 versus the WHO 2017 grading of pancreatic neuroendocrine neoplasms: data from a Large International Cohort Study. Neuroendocrinology 107 375-386. (https://doi.org/10.1159/000494355)

Rindi G, Klimstra DS, Abedi-Ardekani B, Asa SL, Bosman FT, Brambilla E, Busam KJ, de Krijger RR, Dietel M, El-Naggar AK, et al. 2018b A common classification framework for neuroendocrine neoplasms: an International Agency for Research on Cancer (IARC) and World Health Organization (WHO) expert consensus proposal. Modern Pathology 31 1770-1786. (https://doi.org/10.1038/s41379-018-0110-y)

Rizvi SM, Goodwill J, Lim E, Yap YK, Wells AU, Hansell DM, Davis P, Selim AG, Goldstraw P \& Nicholson AG 2009 The frequency of (c) 2020 Society for Endocrinology Published by Bioscientifica Ltd. Printed in Great Britain 
neuroendocrine cell hyperplasia in patients with pulmonary neuroendocrine tumours and non-neuroendocrine cell carcinomas. Histopathology 55 332-337. (https://doi. org/10.1111/j.1365-2559.2009.03371.x)

Rooper LM, Sharma R, Li QK, Illei PB \& Westra WH 2017 INSM1 demonstrates superior performance to the individual and combined use of synaptophysin, chromogranin and CD56 for diagnosing neuroendocrine tumors of the thoracic cavity. American Journal of Surgical Pathology 41 1561-1569. (https://doi.org/10.1097/ PAS.0000000000000916)

Scarpa A, Chang DK, Nones K, Corbo V, Patch AM, Bailey P, Lawlor RT, Johns AL, Miller DK, Mafficini A, et al. 2017 Whole-genome landscape of pancreatic neuroendocrine tumours. Nature 543 65-71. (https://doi.org/10.1038/nature21063)

Schmitt AM, Anlauf M, Rousson V, Schmid S, Kofler A, Riniker F, Bauersfeld J, Barghorn A, Probst-Hensch NM, Moch H, et al. 2007 WHO 2004 criteria and CK19 are reliable prognostic markers in pancreatic endocrine tumors. American Journal of Surgical Pathology 31 1677-1682. (https://doi.org/10.1097/ PAS.0b013e31805f675d)

Seute T, Leffers P, ten Velde GP \& Twijnstra A 2004 Neurologic disorders in 432 consecutive patients with small cell lung carcinoma. Cancer 100 801-806. (https://doi.org/10.1002/cncr.20043)

Simbolo M, Mafficini A, Sikora KO, Fassan M, Barbi S, Corbo V, Mastracci L, Rusev B, Grillo F, Vicentini C, et al. 2017 Lung neuroendocrine tumours: deep sequencing of the four World Health Organization histotypes reveals chromatin-remodelling genes as major players and a prognostic role for tert, RB1, MEN1 and KMT2D. Journal of Pathology 241 488-500. (https://doi.org/10.1002/ path.4853)

Simbolo M, Barbi S, Fassan M, Mafficini A, Ali G, Vicentini C, Sperandio N, Corbo V, Rusev B, Mastracci L, et al. 2019 Gene expression profiling of lung atypical carcinoids and large cell neuroendocrine carcinomas identifies three transcriptomic subtypes with specific genomic alterations. Journal of Thoracic Oncology $\mathbf{1 4}$ 1651-1661. (https://doi.org/10.1016/j.jtho.2019.05.003)

Singhi AD, Liu TC, Roncaioli JL, Cao D, Zeh HJ, Zureikat AH, Tsung A, Marsh JW, Lee KK, Hogg ME, et al. 2017 Alternative lengthening of telomeres and loss of DAXX/ATRX expression predicts metastatic disease and poor survival in patients with pancreatic neuroendocrine tumors. Clinical Cancer Research 23 600-609. (https://doi. org/10.1158/1078-0432.CCR-16-1113)

Solcia E, Klöppel G \& Sobin LH 2000 WHO Classification of Tumours. Histological Typing of Endocrine Tumours, 2nd ed. Lyon, France: Springer.

Sollini M, Farioli D, Froio A, Chella A, Asti M, Boni R, Grassi E, Roncali M, Versari A \& Erba PA 2013 Brief report on the use of radiolabeled somatostatin analogs for the diagnosis and treatment of metastatic small-cell lung cancer patients. Journal of Thoracic Oncology 8 1095-1101. (https://doi.org/10.1097/ JTO.0b013e318293f051)

Swarts DR, Scarpa A, Corbo V, Van Criekinge W, van Engeland M, Gatti G, Henfling ME, Papotti M, Perren A, Ramaekers FC, et al. 2014 MEN1 gene mutation and reduced expression are associated with poor prognosis in pulmonary carcinoids. Journal of Clinical Endocrinology and Metabolism 99 E374-E378. (https://doi. org/10.1210/jc.2013-2782)

Travis WD, Rush W, Flieder DB, Falk R, Fleming MV, Gal AA \& Koss MN 1998 Survival analysis of 200 pulmonary neuroendocrine tumors with clarification of criteria for atypical carcinoid and its separation from typical carcinoid. American Journal of Surgical Pathology 22 934-944. (https://doi.org/10.1097/00000478199808000-00003)
Travis WD, Brambilla E \& Müller-Hermelink H 2004 WHO Classification of Tumours. Tumors of the Lung, Pleura, Thymus and Heart. Lyon, France: IARC Press.

Tsuta K, Kalhor N, Wistuba II \& Moran CA 2011 Clinicopathological and immunohistochemical analysis of spindle-cell carcinoid tumour of the lung. Histopathology 59 526-536. (https://doi. org/10.1111/j.1365-2559.2011.03966.x)

Tsutsumi Y 1989 Immunohistochemical analysis of calcitonin and calcitonin gene-related peptide in human lung. Human Pathology 20 896-902. (https://doi.org/10.1016/0046-8177(89)90103-2)

Uccella S, Blank A, Maragliano R, Sessa F, Perren A \& La Rosa S 2017 Calcitonin-producing neuroendocrine neoplasms of the pancreas: clinicopathological study of 25 cases and review of the literature. Endocrine Pathology 28 351-361. (https://doi.org/10.1007/s12022-0179505-4)

Vesterinen T, Mononen S, Salmenkivi K, Mustonen H, Rasanen J, Salo JA, Ilonen I, Knuuttila A, Haglund C \& Arola J 2018 Clinicopathological indicators of survival among patients with pulmonary carcinoid tumor. Acta Oncologica 57 1109-1116. (https:// doi.org/10.1080/0284186X.2018.1441543)

Vesterinen T, Leijon H, Mustonen H, Remes S, Knuuttila A, Salmenkivi K, Vainio P, Arola J \& Haglund C 2019 Somatostatin receptor expression is associated with metastasis and patient outcome in pulmonary carcinoid tumors. Journal of Clinical Endocrinology and Metabolism 104 2083-2093. (https://doi. org/10.1210/jc.2018-01931)

Volante M, Gatti G \& Papotti M 2015 Classification of lung neuroendocrine tumors: lights and shadows. Endocrine 50 315-319. (https://doi.org/10.1007/s12020-015-0578-x)

Yachida S, Vakiani E, White CM, Zhong Y, Saunders T, Morgan R, de Wilde RF, Maitra A, Hicks J, Demarzo AM et al. 2012 Small cell and large cell neuroendocrine carcinomas of the pancreas are genetically similar and distinct from well-differentiated pancreatic neuroendocrine tumors. American Journal of Surgical Pathology $\mathbf{3 6}$ 173-184. (https://doi.org/10.1097/PAS.0b013e3182417d36)

Yang MX, Coates RF, Ambaye A, Cortright V, Mitchell JM, Buskey AM, Zubarik R, Liu JG, Ades S \& Barry MM 2018 NKX2.2, PDX-1 and CDX-2 as potential biomarkers to differentiate well-differentiated neuroendocrine tumors. Biomarker Research 6 15. (https://doi. org/10.1186/s40364-018-0129-8)

Yao JC, Fazio N, Singh S, Buzzoni R, Carnaghi C, Wolin E, Tomasek J, Raderer M, Lahner H, Voi M, et al. 2016 Everolimus for the treatment of advanced, non-functional neuroendocrine tumours of the lung or gastrointestinal tract (RADIANT-4): a randomised, placebo-controlled, phase 3 study. Lancet 387 968-977. (https://doi. org/10.1016/S0140-6736(15)00817-X)

Zaffaroni N, Villa R, Pastorino U, Cirincione R, Incarbone M, Alloisio M, Curto M, Pilotti S \& Daidone MG 2005 Lack of telomerase activity in lung carcinoids is dependent on human telomerase reverse transcriptase transcription and alternative splicing and is associated with long telomeres. Clinical Cancer Research 11 2832-2839. (https:// doi.org/10.1158/1078-0432.CCR-04-1293)

Zhang L, Smyrk TC, Oliveira AM, Lohse CM, Zhang S, Johnson MR \& Lloyd RV 2009 KIT is an independent prognostic marker for pancreatic endocrine tumors: a finding derived from analysis of islet cell differentiation markers. American Journal of Surgical Pathology 33 1562-1569. (https://doi.org/10.1097/PAS.0b013e3181ac675b)

Zhang JT, Li Y, Yan LX, Zhu ZF, Dong XR, Chu Q, Wu L, Zhang HM, Xu CW, Lin G, et al. 2020 Disparity in clinical outcomes between pure and combined pulmonary large-cell neuroendocrine carcinoma: a multi-center retrospective study. Lung Cancer 139 118-123. (https://doi.org/10.1016/j.lungcan.2019.11.004)

Received in final form 23 July 2020

Accepted 3 September 2020

Accepted Manuscript published online 4 September 2020 https://erc bioscientifica.com https://doi.org/10.1530/ERC-20-0122 (c) 2020 Society for Endocrinology Published by Bioscientifica Ltd. Printed in Great Britain 